\title{
IRRACIONALIDAD POPULAR EN EL ARTE FIGURATIVO ESPAÑOL DEL SIGLO XVIII
}

Jesusa VEGA

La ignorancia $[\ldots]$ no se debe por ningún motivo defender, sino darle muchas gracias al que nos la descubre, para que huyamos de tan horrendo monstruo (Ponz [1772] 1947, vol. I, pág. 2).

La irracionalidad, entendida como expresión de la ignorancia y la superstición, fue tenaz y continuamente criticada por los ilustrados españoles que veían, en la mayoría de sus compatriotas, una clara tendencia al fanatismo como consecuencia de unas carencias seculares de educación y cultura'. Las expresiones plásticas de estos comportamientos irracionales en términos ilustrados eran, por ejemplo, los que habían adornado los templos de disparatados altares llenos de hojarascas, en palabras de Ponz ${ }^{2}$, las imágenes sagradas que movían a la piedad sin apenas atender al buen gusto, los amuletos y dijes que alejaban al demonio, etc. A pesar de una decidida voluntad de los ilustrados por desterrar de los comportamientos sociales manifestaciones ajenas a la razón, se da una perpetuación de costumbres e imágenes irracionales de las que conservamos

1 Por supuesto no fue sólo patrimonio de los ilustrados la crítica a expresiones de ignorancia y superstición. Una prueba evidente de la lucha de los sectores más cultos de la sociedad frente a la credulidad de las gentes es el sistemático ataque a la falsa existencia de las brujas, y de ello da testimonio el estudio de Lisón Tolosana, 1992. No obstante, aunque tanto la crítica cómo la sátira hacia comportamientos irracionales no eran novedosas en la España del XVIII, sin duda se agudizaron en este siglo entre los ilustrados. Hubiera sido imposible redactar este texto sin la ayuda y colaboración de Antonio Correa, José Manuel Matilla y Javier Portús. A ellos, amigos y aficionados, según expresión ilustrada, de la estampa, les agradezco su colaboración. También agradezco a Nigel Glendinning y a Guillermo Carnero su ambilidad por haberme invitado a participar en el Curso Superior de Filología de la UIMP de 1992.

2 Ponz, 1947. La primera edición se publicó en 18 volúmenes entre 1772 y 1794. De los 13 primeros volúmenes hubo una segunda edición entre 1776 y 1788 , y se hizo la tercera edición de los 6 primeros entre 1787 y 1793 . 
testimonios gráficos coetáneos a través de las estampas ${ }^{3}$ y escritos contemporáneos. En esta ocasión vamos a contrastar las opiniones de aquellos que reflejan o respetan los gustos y creencias populares y autores que tratan de enjuiciar desde la razón aunque, en muchas ocasiones acaben adoptando un tono burlón como lo demuestran algunos textos de Leandro Fernández de Moratín o de Blanco White, incluso del mismo Antonio Ponz.

Valenciano de origen, amante de las bellas artes y educado con los jesuitas, Ponz abandonó los estudios de Teología sin llegar a ordenarse sacerdote para dedicarse, casi exclusivamente, al estudio de las distintas manifestaciones artísticas que, en España, habían tenido su principal medio en el ámbito de las creencias religiosas. Ilustrado y relacionado con los círculos jansenistas debía ser habitual en él emplear "la tarde en ver iglesias, que es donde suele estar lo que hay de bueno". En otra parte de su Viaje por España escribe:

Repetidas veces he dicho y no es menester decirlo, porque todos Io saben, que las iglesias es lo primero que se va a ver en las ciudades y pueblos, porque dan por supuesto que en ellas es donde se halla lo más precioso, lo más digno y bien ejecutado de cada país (Ponz, 1947, pág. 964).

Pero si allí era donde arquitectura, pintura y escultura encontraban su mayor desarrollo, también allí era donde se reunían los frutos de la impericia e irracionalidad de artistas y mecenas que habían educado durante décadas el gusto del vulgo, un vulgo o muchedumbre ignorante a la que Ponz, como buen ilustrado, creía que había que reeducar: "Cuán lejos debe estar del que tiene amor a los suyos el dejarlos recrear en sus delirios, por más gusto y placer que en ellos encuentren, y de no poner cuantos medios sean posibles para volverlos en sí, aunque mucho lo repugnen", porque "si el vulgo gusta de estas figuras [...] es porque no le ponen otra cosa a la vista, ni se le instruye", ya que "estas cosas", continua Ponz, "no nacen de la impiedad, sino de la ignorancia; y siendo así, no hay razón para que pudiendo desterrarse, no se destierre (Ibíd, pp. 302-303).

De ninguna mano mejor podríamos acercarnos a las manifestaciones artísticas que para los ilustrados eran fruto de la irracionalidad y del mal gusto. Para Ponz, como para muchos otros ilustrados, la piedad popular y la religiosidad tenían una expresión plástica y un ceremonial que había que modificar y renovar profundamente. Ponz se sirve de su Viaje de España para opinar, criticar, censurar y dar nuevos modelos de actuación.

3 Las estampas que sirven de ilustración al texto pertenecen a la colección madrileña de Antonio Correa. El conjunto es un repertorio representativo del tipo de grabado que estaba vigente en España durante el siglo XVIII (la talla dulce académica, el grabado en madera popular) y se completa con las estampas al aguafuerte y aguatinta de Francisco de Goya, que por ser las más conocidas hemos obviado reproducir. Por otro lado, es importante recordar que entre los artífices españoles se dio una especialización local en la producción de estampas religiosas, por lo que todas las que se reproducen, incluidas las anónimas, son españolas. 
El primer arte que se va a tratar es el de la arquitectura referida al adorno interior de los templos. Al tratar de Guadalajara Ponz comenta:

Ya sabe V. cuan rematada cosa son, por falta de artificio, tantos altares como en nuestros días se han ido ejecutando, sin valerse para ello de los que hubieran sabido hacerlos con toda propiedad [...] entre los cuales deben tener el ínfimo lugar los que se han ejecutado en el siglo presente. Yo bastantes especies procuro sembrar, para que, supuesto que en esa Corte hay en el día sujetos capaces y que han estudiado Arquitectura como se debe estudiar, se valgan de ellos; y también cito las obras que han hecho con acierto, inteligencia, y aplauso (Ibíd, pág. 122).

De esta manera se resume la labor llevada a cabo desde las instituciones oficiales por desterrar el Barroco e introducir entre el vulgo el buen gusto, es decir, la conocida como arquitectura neoclásica.

Entre las mejores estampas que conservamos en la que se aprecia el retablo barroco en todo su esplendor y riqueza están las que muestran a la Virgen de la Soledad de Madrid (fig. 1) "como se venera en su capilla y retablo", o a la Virgen de la Novena (Arte y devoción, 1990, núm. 41). Su aspecto se ajusta a las fórmulas que espantaban a Ponz:

Cornisamentos rotos, frontispicios dentro de frontispicios, cuerpos multiplicados sobre un mismo plano, nichos que no vienen al caso, pilastras y columnas agrupadas para no sostener cosa alguna, líneas tortuosas por rectas, adornos fuera de propósito, y últimamente miembros que no se puede atinar lo que significan, se descartarán ciertamente (Ibíd, pág. 318$)^{4}$.

Otro de los elementos irracionales que horrorizaban a don Antonio eran las columnas salomónicas:

Puestas por fin en tantos altares monstruosos, que con el arte nada tienen que ver, no hemos de hacer alto en ellas. Estas columnas retorcidas, no se con qué fundamento llamadas salomónicas, sólo las pudo sostener la novedad y el capricho: escollo en que se precipita la razón de casi todos los hombres, cuando se trata de las bellas artes. Si las columnas deben ser la imitación de un tronco de árbol, ¿en dónde se hallan árboles de semejante figura? Y si se hallasen en una parte, o en muchas ¿quién sino un loco los hubiera escogido para adornar y sostener aquellos primeros edificios que han sido la norma de lo que adelantaron después los buenos arquitectos? Dirá alguno que el célebre altar mayor del Vaticano tiene columnas

4 Opinión compartida por Jovellanos en su Elogio de don Ventura Rodríguez (Jovellanos, 1956, pág. 372): "Cornisamentos curvos, oblicuos, interrumpidos y ondulantes; columnas ventruadas, tabidas, opiladas y raquíticas; obeliscos inversos, sustituidos a pilastras; arcos sin cimiento, sin base, sin imposta, metidos por los arquitrabes, y levantados hasta los segundos cuerpos; metopas injertas en los dinteles, y triglifos echados en las jambas de las puertas; pedestales enormes, sin proporción, sin división ni miembros, o bien salvajes, sátiros y aun ángeles, condenados a hacer su oficio; por todas partes parras y frutales, y pájaros que se comen las uvas, culebras que se emboscan en la maleza; por todas partes conchas y corales, cascadas y fuentecillas, lazos y moños, rizos y copetes, bulla y zambra y despropósitos insufribles; he aquí el ornato, no sólo de los retablos y hornacinas, sino también de las puertas, pórticos y frontispicios, y de los puentes y fuentes de la nueva arquitectura". 


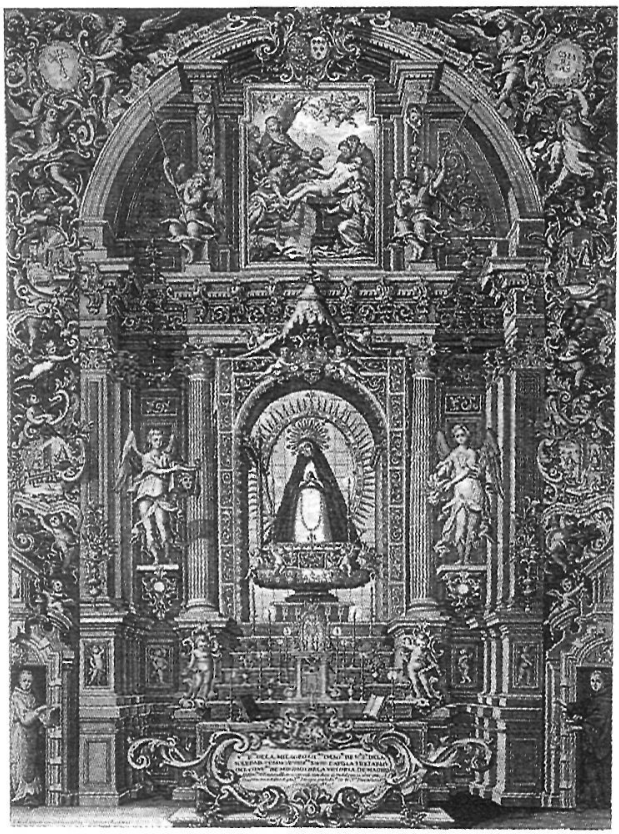

Fig. 1. Virgen de la Soledad. Dibujada y grabada en cobre por Matías Irala en 1726.

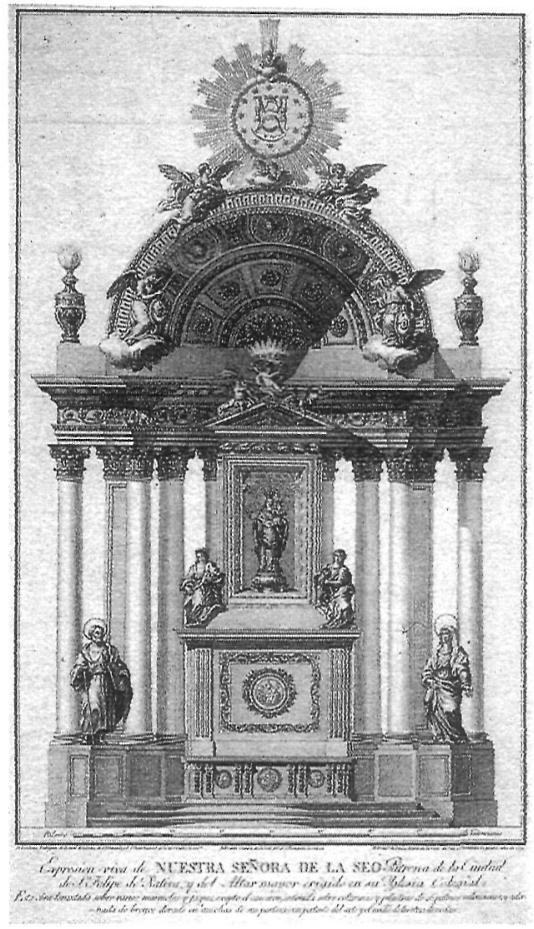


salomónicas, y que las hay en otras obras de gran reputación. En cualquier parte que estén las criticará, háyalas hecho quien quiera, el hombre que busca la razón y origen de las cosas (Ibíd, pág. 368).

La riqueza sinuosa de las columnas del retablo de la Virgen de la Novena (Arte y devoción, 1990, núm. 41) contrasta con la desnudez y escaso volumen de las que parecían adornar el retablo de la Virgen Mayor de la catedral de Sigüenza y que se aprecian en la estampa de Lorenzo Sánchez Mansilla, grabado hecho a devoción de Francisco Gutiérrez Urraca (Páez, 1981, núm. 1983-2), quizá por un deseo intencionado de simplificar los excesos barrocos del retablo. Ésta es otra de las circunstancias dignas de comentario. Las denuncias de Ponz no cayeron en saco roto, y además de establecerse una nueva legislación que impedía continuar con esas costumbres de época barroca, se mandó que las obras de arquitectura fueran vistas y aprobadas por la Academia. Pero no todos los retablos o adornos de buen gusto que conocemos a través de las estampas existieron en realidad. Con sus críticas Ponz no pretendía, como él mismo declara, censurar el adorno de las iglesias sino quitar "ciertos adornos impropios de las casas de Dios, que sirven de hacer reír a los que conocen las Artes", es decir limpiar y hermosear las iglesias desembarazándolas de objetos extravagantes y ridículos retablos de madera, pero esto en ocasiones sólo se llevó a cabo de forma imaginaria, a través del grabado, en las estampas.

Entre los altares antiguos Ponz pone por modelo el gran altar de la Iglesia del Oratorio del Salvador:

De varios mármoles y bronces en el mismo crucero al lado del Evangelio, se trabajó en Roma, y fue éste de los primeros que en este siglo sirvieron de ejemplo para ejecutar cosas verdaderamente grandes y nobles. Consiste principalmente en cuatro columnas de mármol verde sobre el basamento, con sus capiteles de orden compuesto. En el medio hay un relieve cuyas figuras son del tamaño natural [...] Sobre la cornisa hay puestos otros dos ángeles mancebos, y toda la obra es de lo mejor que hay en los templos de Madrid (Ibíd, pág. 464).

A lo largo de su texto Ponz pone por modelo a Ventura Rodríguez y a Juan de Villanueva. Un buen ejemplo del tipo de adorno que se consideraba ajustado a la razón en la mente de nuestros ilustrados es el altar de Nuestra Señora de la Seo, Patrona de la Ciudad de San Felipe de Játiva, cuya estampa (fig. 2) muestra el altar mayor erigido por invención de Ventura Rodríguez y Juan Guixart, ambos académicos de Nobles Artes, el primero de la de San Fernando de Madrid, y el último de la de San Carlos de Valencia.

5 A pesar de la riqueza de nuestro patrimonio en estampas religiosas, aún en la actualidad no hay abundantes repertorios gráficos sobre este tema. Desde esta perspectiva resulta sin duda fundamental el catálogo de la exposición Arte y devoción, 1990. 
De esta manera podemos comentar la doble función que tenía este tipo de estampas: con la excusa de una estampa de devoción se introducían los modelos arquitectónicos que Ponz y los profesores de las Nobles Artes querían hacer familiares al vulgo. Esa clara finalidad de educar visualmente al pueblo se pone de manifiesto en el comentario que encontramos en la estampa de la Virgen de la Seo, obra de Francisco de Paula Martí, también de la Real Academia de San Fernando: "Esta obra levantada sobre varios mármoles y jaspes, excepto el cascarón, sostenida sobre columnas y pilastras de 26 palmos valencianos, y adornada de bronce dorado en muchas de sus partes, es un portento del arte y el exidio de las otras de su clase". Y lo mismo ocurre con la enorme estampa de la Virgen del Pilar (fig. 3) "según se venera en su magnífico tabernáculo, manifestándose parte de los cuatro machones, sus arcos, pechinas, con su respectiva media naranja de la iglesia, en cuyo espacio esta dicha fábrica", dibujada y grabada por Mariano Latasa en 1805; los 9.020 días de indulgencia que se podrían ganar ante ella más parecen una excusa para dar a conocer la arquitectura ideada por Ventura Rodríguez para la venerada imagen de la Virgen, que apenas si se ve en la parte derecha de la estampa ${ }^{6}$. Era ésta una de esas estampas que consideraría convenientes Ponz, pues también su interés y preocupación por el arte del grabado como firme aliado para difundir el buen gusto le llevaba a lamentarse cuando era empleado de manera inadecuada:

Se ha gastado el tiempo, el dinero y el cobre en representar ridículos altares de talla, imágenes que por su fealdad debían apartarse de la vista de los fieles y otras tales cosas muy conducentes para radicar el mal gusto; y de tantos objetos peregrinos, de tantos prodigios del arte, no se ha hecho caso para este efecto (Ibíd, pág. 555).

El adorno y la iluminación eran fundamentales en los diferentes actos religiosos. Según fuera la iluminación se podía conseguir de la audiencia recogimiento, miedo o admiración. Cuando Blanco White comenta el entorno en el que se desarrollaban los ejercicios espirituales, explica cómo la primera reunión en la capilla se hacía con la estancia casi a oscuras, tan sólo una "lamparilla, cegada por todos los lados excepto uno, iluminaba tenuemente la estatua de un Cristo agonizante en la cruz. Como el artista se había propuesto impresionar los sentidos, sin ninguna consideración por el gusto, la estatua era

6 Cinco años antes el mismo grabador había publicado una Vista exterior e interior del magnífico tabernáculo de Nuestra Señora del Pilar. Se encuentra reproducción de la estampa en el catálogo de la exposición Ventura Rodríguez, 1983, núm. 18. Conviene recordar que la estampa que siempre tuvo una demanda constante en España fue la de carácter religioso. El ejemplo más elocuente de esta realidad lo encontramos en la actividad desarrollada por el mejor grabador español en talla dulce y maestro de grabadores, Manuel Salvador Carmona; un 30\% de su producción está formada por estampas de devoción. 
Fig. 3. Virgen del Pilar. Dibujada y grabada en cobre por Mariano Latasa en 1805.

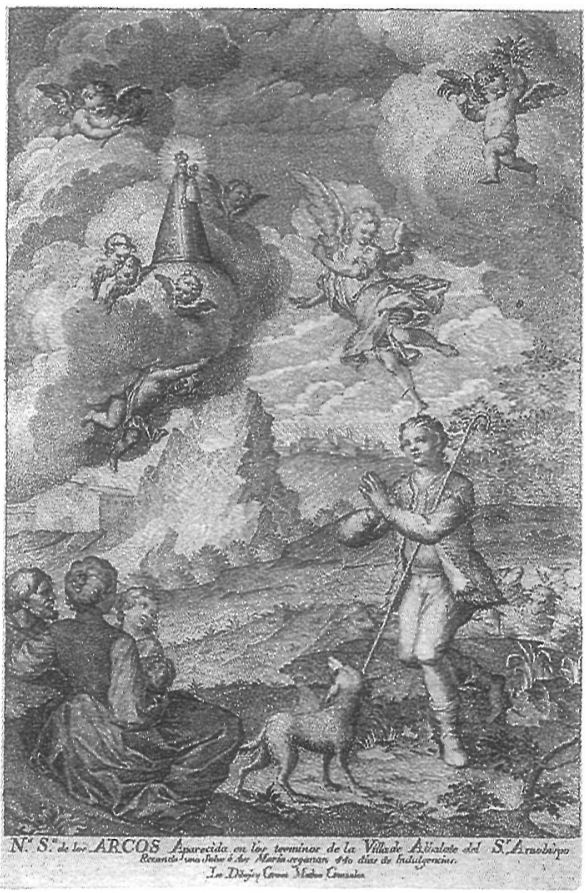

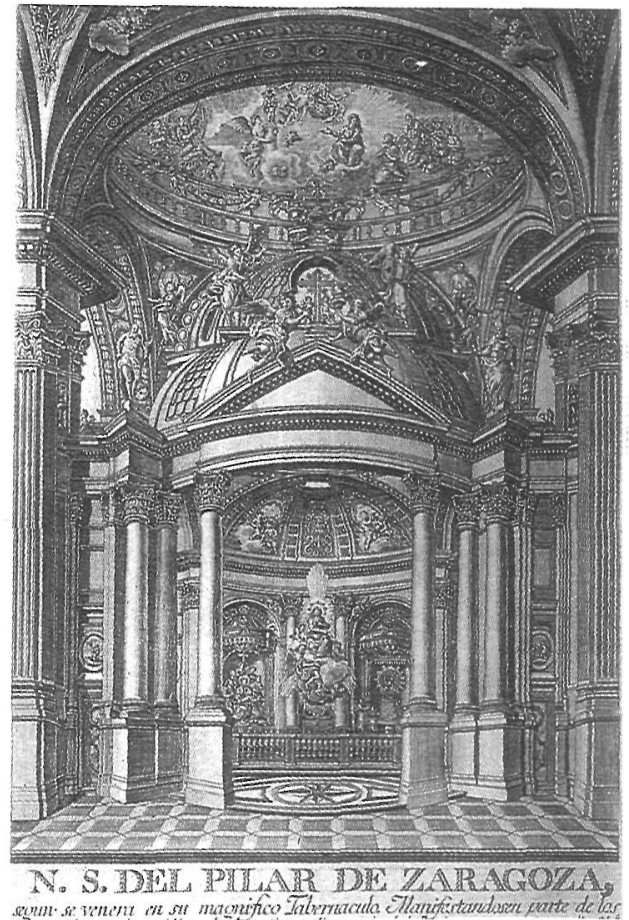

Fig. 4. Virgen de los Arcos. Dibujada y grabada en cobre por Mateo González. 
de tamaño natural, con ojos de vidrio y el cuerpo coloreado de tal modo que reproducía los cuajarones de sangre que salpicaban la carne". Avanzados los ejercicios, y después de haber consagrado un día al tema de los castigos eternos, venía la tarde de la meditación en la que se hablaba de gracia y esperanza. El aspecto de la capilla contribuía al cambio de sentimientos: "Entonces no era una tumba sombría como antes; en el altar había velas de cera en medio de las cuales una imagen sonriente de la Virgen María parecía saludar a los acongojados penitentes que entraban" (Blanco White, 1972, pp. 122-124).

Lámparas, luminarias y velas eran fundamentales en el entorno sagrado de iglesias, capillas, etc. En muchas fábricas se amontonaban las lámparas de plata para disgusto de Ponz. En la iglesia de Illescas el erudito comenta:

Lo que más ha desfigurado esta iglesia es un especie de balcón con balaustres, que corre desde la capilla mayor hacia el crucero, rompiendo las pilastras de orden corintio que allí hay, y sólo parece haberse hecho el tal balcón para amontonar en él cerca de cincuenta lámparas de plata, como si consistiera en esto la magnificencia y la verdadera devoción (Ponz, 1947, pág. 26).

Pero eran muchos los altares que habían sido transformados a lo largo de los tiempos con el fin de facilitar la iluminación. Para ello se añadían al altar graderías de madera - ejemplo de esas graderías se aprecian en las estampas comentadas anteriormente- lo que había provocado la existencia de "infinitos rimeros de madera dorada", según Ponz, quien apostilla "en tal grado, que para ponerlos se han quitado muchos, que si bien eran de la misma materia, se veía en ellos alguna razón de arquitectura. ¡Qué gastos! ¡Qué diligencias! ¡Qué aturdimiento para llenar los templos de los objetos más quiméricos, que a entendimiento humano podían ocurrir!” (Ibíd, pág. 407).

Entre los ejemplos que más indignaban a Ponz se encontraba el altar mayor del convento de monjas de Santo Domingo de Loeches, sobre cuya mesa de altar había un tabernáculo de orden corintio de ébano, lapislázuli y varios metales, todo ello de buen gusto:

Mas para que en tan peregrino altar no faltase una chafarrinada comenta el ilustrado-, sepa V. que han colocado sobre la mesa una gradería en que puedan poner muchas luces, y algunos santos de madera mal hechos, sirviendo esto para ocultar las imágenes dignas de los cuadros, los escalones para cubrir los bellísimos cuadritos del basamento y la multitud de luces cuando las pongan para ennegrecer todo lo pintado, y acaso para quemarlo algún día (Ibíd, pág. 106).

En la iluminación de los templos el valenciano consideraba que debía seguirse el modelos de las "iglesias más serias, esto es, las Catedrales, [que] regularmente se sirven de seis velas, o pocas más, sobre la mesa del altar, aun en las mayores solemnidades. Cuando el mismo Papa celebra, y los obispos, 
sólo se añade una a las seis que se han dicho: con que lo demás ya es en cierto modo desviarse de los ejemplos que se deben seguir. Ha de añadirse que con cuatrocientas o quinientas velas, como frecuentemente se amontonan en nuestros retablos [...] es una distracción para los que se hallan en el templo el ver cruzar todo el altar desde arriba abajo los que andan ocupados en encender tantas luces: un continuo cuidado en observar, como en las decoraciones teatrales, si se tuerce una vela, o si cae un pábilo que pegue fuego en un instante a toda la máquina" (Ibíd, pág. 432).

A esto se añadía el riesgo a perder la vida por parte de estos empleados:

¿Cuántas veces — se pregunta Ponz - ha causado a muchos la muerte la ridícula operación de ir cruzando por los retablos para encender tantas velas, cayendo desde lo alto, como en el mes de Enero de 1776 sucedió en la Iglesia de los Premonstratenses [de Madrid] a José García, que aunque no murió, estuvo a los últimos de su vida? (Ibíd, pág. 407).

Pero, por si no fuera suficiente con estas críticas a la iluminación, Ponz expone también su severa opinión sobre los adornos de estos espacios sagrados:

Si adornan las iglesias con motivo de festividades, ¿en dónde se hace con gusto e inteligencia? Con amontonar muchos platos, bandejas, jarrones, soperas y cosas semejantes, poniendo en el santuario todo el aparato profano de un convite, ya piensan haber hecho cosa grande. Cualquier ornato extraño debería desterrarse de los templos; pero éste con más razón, por ser indecente y ridículo (Ibíd, pág. 407).

Y en otra parte de su texto se pregunta:

¿No sería cosa muy propia el que los prelados cuidasen en despojar los altares de ciertas puerilidades contrarias a la majestad que les corresponde, ejecutadas sin ningún arte, y que los trasforman en unos espectáculos teatrales impropios de los templos, y tan contrarios al buen gusto y seriedad que debe reinar en la casa del Señor? Esto no podría lograrse sin que la celasen sujetos de inteligencia, y sin rehusar lo que para este fin ofrecen ciertas personas buenas, que creyendo hacer una gran cosa no lo logran; antes bien todo lo contrario, poniendo en el santuario lo que no debía estar sino muy lejos de él. Es mucha lástima que estos tales no se informen antes de los que entienden, y así emplearían sus ofertas mucho mejor de lo que comúnmente vemos. ¿Y qué diremos del uso disparatado mediante el cual en las festividades transforman los altares en un aparador de todo género de vajilla de plata, como si en aquella iglesia se hubiese de servir una gran comilona? Otra usanza me han asegurado que se ha introducido, aún mas ridícula, por los altareros; y es que esta vajilla se hace ya en muchas partes de cartón plateado, porque solían robar la verdadera plata entre la bulla de las funciones; y así siendo este ornato una extravagancia, como cualquiera conoce, aun cuando concurría la preciosidad del metal, se deja ver cuánto más despreciable es en materia tan vil como el cartón (Ibíd, pág. 107).

Todas estas actuaciones eran motivo para que se riesen las gentes de juicio y de buen gusto. Pero, además, entre las consecuencias que tenía la iluminación de los templos se encuentra el continuo ennegrecimiento de retablos e imágenes, 
amén del riesgo permanente de incendio, tema de interés pero del que no vamos a ocuparnos en esta ocasión. Hoy en día estamos acostumbrados a contemplar muchas de las vírgenes con tez oscura, pero es evidente que en su día no eran imágenes morenas, sino que el paso del tiempo ha ido ennegreciéndolas. Ponz lo explica así al tratar de la patrona de Madrid, la Virgen de la Almudena, que se veneraba en una capilla oscura, junto a la sacristía, de la parroquia de Santa María:

Aunque el altar mayor es rico de plata, en cuanto al arte no lo es. La imagen de nuestra Señora que se venera en él, llamada de la Almudena, es patrona de Madrid, y uno de los objetos más principales de su devoción [...] Visten la imagen con ricas telas y la adornan de pedrería como a la de Atocha. Ambas tienen el color muy obscuro, porque con la antigüedad el albayalde de que se hizo la encarnación, que no es otra cosa que plomo, se ha convertido en su natural color, a que habrá ayudado no poco el humo continuo de las luces. Por la misma causa, y no por otra, tienen el mismo color todas las imágenes antiguas hechas de madera (Ibíd, pág. 453).

El centro de los retablos y de las devociones lo ocupaban lógicamente las imágenes. Muchas de estas imágenes eran, en opinión de Ponz, verdaderos errores que se proponían al entendimiento o se presentaban a la vista:

¿Y qué mayor [error] para ésta — se refiere a la vista—como representar a Jesucristo y a sus santos en figuras feas, dislocadas, sin proporción ni parte ninguna en su lugar? ¿Destínanlas después a que el devoto pueblo las venere en aquellos informes retablos cuyos ornatos suelen consistir en colgajos de berzas, en bichos y otras sabandijas? (Ibíd, pág. 964).

Nos vamos a ocupar seguidamente de las esculturas, más concretamente de las imágenes de la Virgen, sirviéndonos, para introducirnos en el tema, de la ingenua estampa de la Virgen de los Arcos (fig. 4) donde el grabador muestra la aparición de la Virgen a un pastor. Las pautas de cómo se generaba la historia y la leyenda de la mayoría de estas imágenes marianas veneradas en el siglo XVIII sería la siguiente: hallazgo de una imagen por un joven, frecuentemente pastor, y que estaba en ese lugar de modo ocasional; a partir de este momento comienza el proceso de extensión de la creencia, que suele ser rápida entre las capas populares pero encuentra reticencias entre las clases altas y las instituciones religiosas (Velasco, 1989, pp. 401-410). El esquema o pauta que hemos descrito llegó a ser tan habitual que incluso los falsos santeros habían asimilado la manera de narrar estas actuaciones sobrenaturales. Puede ser un ejemplo la historia de Francisco Martínez? Primero se inventó que tenía un Santo Cristo que llevaba en el pecho y que sudaba sangre —el impostor admitió que mojaba el crucifijo y después él se hacía sangre y se la pegaba-, pero como se lo quitaron, después ideó la siguiente historia: "Se le apareció una imagen de nuestra Señora pequeñita, muy morena y con vestidos al parecer naturales,

7 Christian, 1989. En las obras de este mismo autor (1981 a, y b) se basó Velasco, 1989, para hacer su estudio. 
acercándose a él al modo como anda una paloma y que le dijo «Devoto mío del rosario, baja al pueblo y di que vengan por mí», y allí la encontraron a "la Divina Señora en una peña que llamaban Barrancos". La realidad es que Martínez había robado la imagen en Priego, su pueblo natal, de un nicho al lado de una de las puertas de la ciudad, para engañar a sus convecinos de Taravilla, aldea a $40 \mathrm{~km}$. de Priego. Muchas de estas imágenes tenían además la singularidad de que el artífice había sido a su vez un santo, o habían sido labradas por algún ser divino, o gracias a algún tipo de intervención sobrenatural. En este último caso estaría la Virgen de la Soledad de Madrid (fig. 1) ${ }^{8}$ y en el primero la Virgen de Valvanera (fig. 5).

Hay que poner de relieve que, tanto en la narración de Martínez como en la estampa de la Virgen de los Arcos, la imagen aparece vestida. La riqueza del guardarropa de la imagen era consecuencia casi directa de la mayor o menor devoción que existía hacia ella. Antes de introducirnos en el tema de las imágenes vestidas, conviene tener presente que la devoción a determinadas imágenes no era algo exclusivo del vulgo, sino que la misma familia real tenía sus predilecciones en estas cuestiones. A modo de ejemplo, podemos citar que en su testamento la reina Bárbara de Braganza hizo mandas a diversos conventos: "un ramo de diamantes a la Virgen del convento lisboeta de la Madre de Dios, otro de brillantes y rubíes y uno de sus vestidos más costosos a la imagen de la Virgen del Patrocinio que se venera en El Escorial, otros vestidos a las Vírgenes de Atocha y Guadalupe, seis candeleros de plata al Cristo de El Pardo" (Rodríguez G. de Ceballos, 1987, pág. 199). Estas predilecciones entre una u otra imagen eran comunes entre la población y fueron puestas en solfa de esta manera en El Censor:

El [culto] que se rinde vulgarmente a las imágenes, jcuán ajeno es del espíritu con que la Iglesia las venera! ¡Cuánto se mezcla de idolatría en esta mayor devoción a la Divina Pastora que a la Peregrina, o a la Peregrina que a la de la Leche! ¡Al San Antonio de Piedra que al de San Francisco el Grande, o a éste que al de los Portugueses! [...] Hay muchos que imaginan en las imágenes un no se qué de divino que, independientemente del original que representan y sin relación a él ninguna, atrae su atención (Censor, 1972, pp. 83-84).

La costumbre de vestir imágenes era otra de las expresiones más irracionales en opinión de los ilustrados. Esta costumbre tenía su origen en los oratorios y capillas privadas que los nobles poseían en sus palacios, en los cuales las imágenes de bulto recibían vestiduras a modo de aderezo. Pronto surgieron las críticas; por ejemplo San Juan de la Cruz en La subida al Monte Carmelo (cap. XXXV) escribe:

8 En la estampa se hace una breve relación de las circunstancias en las que Gaspar Becerra hizo la imagen. La historia completa con toda suerte de detalles se puede consultar en Ares, 1640. 


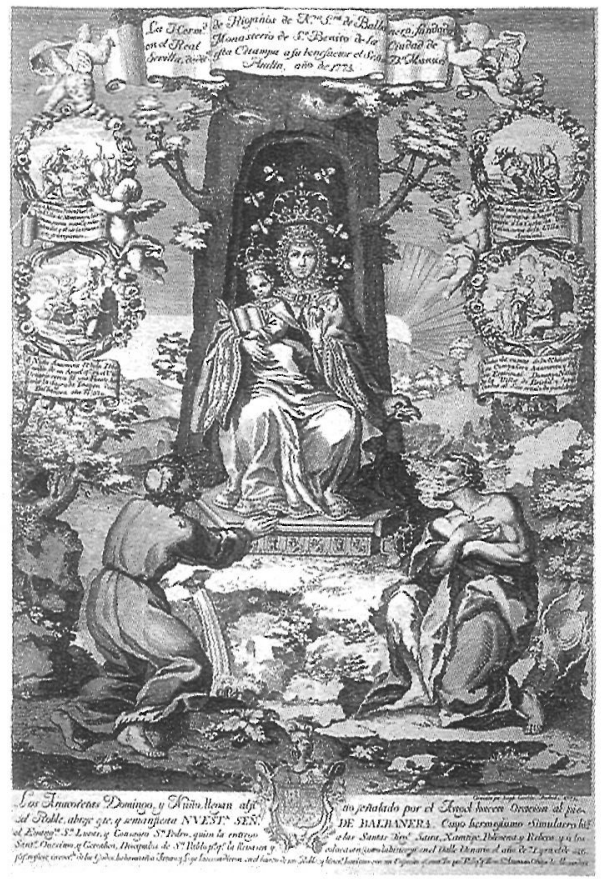

Fig. 5. Virgen de la Valvanera. Grabada en cobre por José Giraldo en 1775.

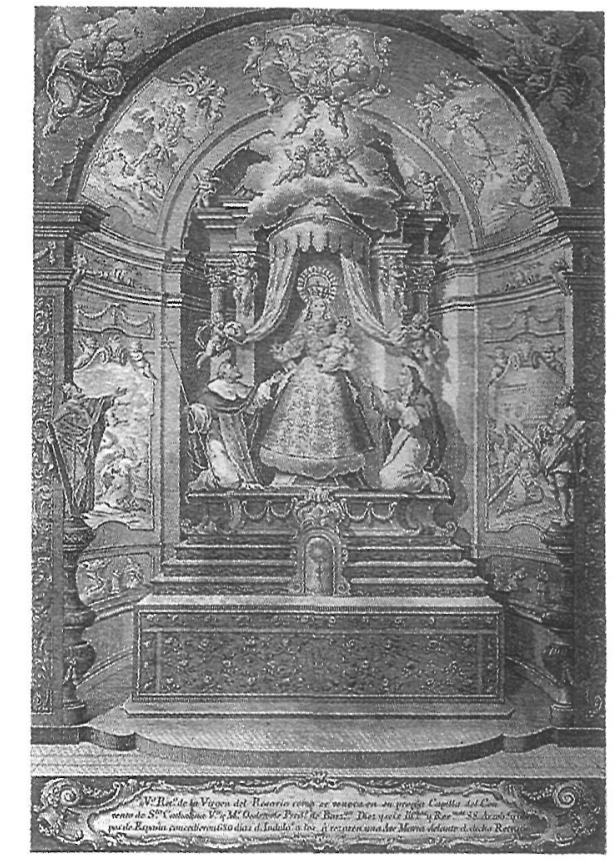

Fig. 6. Virgen del Rosario. Grabada en cobre por Mateo González. 
Esto se verá bien por el uso abominable que en estos tiempos usan algunas personas, que no teniendo ellas aborrecido el traje que la gente vana por tiempo va inventando para el cumplimiento de sus pasatiempos y vanidades, y del traje que en ellas es reprendido, viste las imágenes, cosa que a los santos que representan fue tan aborrecible [...] y de esta manera la honesta y grave devoción del alma [...] ya se les queda en poco más que en ornato de muñecas, no sirviéndose alguno de las imágenes en poco más que de unos ídolos en que traen puesto su gozo (cit. Martínez-Burgos García, 1990, pág. 151. Véase también Rodríguez G. Ceballos, 1989).

El carácter íntimo y particular del oratorio no era acorde con el afán de ostentación que en ellos había, por lo que progresivamente se produjo un cambio de mentalidad en la que el gusto por lo privado fue sustituido, poco a poco, por la exposición pública.

Bernardino de Villegas escribía en 1635:

De la afición a las galas, que dijimos arriba nace en algunas personas por un abuso digno de remedio, y es que, como por una parte tiene esta aficioncilla arraigada en el corazón, y por otra su estado no permite la superfluidad de las galas y dijes que apetecen para parecer bien, viene a ser que a las santas que tienen en sus oratorios las visten de damas muy bizarras y compuestas; y si bien suele ser este abuso más ordinario y común en el mundo, y truco muy usado, en que a las imágenes las visten ya de damas, y a las damas las visten de imágenes: pero también suele haber en esta materia algún abuso en personas virtuosas; de las cuales algunas, como traen el alma galana allá dentro, visten a los santos de sus oratorios con tantos dijes y galas, que es cosa indecentísima; y a veces le da a un hombre gana de reír viendo las brujerías que ponen a los santos; y otras de 1lorar, mirando la indecencia con que los santos y santas son tratados. ¿Qué cosa más indecente que una Imagen de nuestra Señora con saya entera, ropa, copete, valona, arandela, gargantilla y cosas semejantes? ¿Y unas santas vírgenes vestidas tan profanamente y con tantos dijes y galas que si las adorará por Santa Lucía o Santa Catalina, o si apartará los ojos por no ver la profanidad de sus trajes: porque sus vestidos y adorno no parecen santas del cielo, sino damas del mundo: y a no estar Santa Catalina con su espada en la mano, y Santa Lucía con sus ojos en el plato, por lo que toca al vestido y traje galán con que las visten nadie dijera que eran santas, ni vírgenes honestísimas como lo fueron (Villegas, 1635, pp. 430-31, cit. Caro Baroja, 1985, pág. 134).

A medida que las cofradías y hermandades sacramentales adquieren un status propio, generan un tipo de imagen que les es específico y que forma capítulo aparte dentro de la iconografía barroca. Bajo su impulso es cuando se van conformando las imágenes de vestir —conocidas también como imágenes de devanadera (fig. 1) - plenamente barrocas, es decir, esos armazones de madera a manera de maniquíes - a veces incluso articulados- en los que únicamente se tallaban las manos, pies y rostro, quedando el resto oculto bajo el despliegue de sedas, brocados y damascos. A la vez se procede a vestir imágenes anteriores. De esta manera la imagen habitual que tenemos de las vírgenes dieciochescas es la de una Virgen con el Niño a los que apenas se les ve el rostro y las manos. El resto subyace bajo enormes y ricos vestidos. 
Por ejemplo, Jovellanos al expresar en su Carta Décima a don Antonio Ponz (Jovellanos, 1952, pág. 310) su opinión contraria al valor estético de la imaginería religiosa de su tiempo, aduce como causas no sólo la exigua capacidad artística de la época, sino además otras extravagancias propias del mal gusto y la superstición reinante:

Tal es la de sobreponer valonas y vueltas de encaje a las vestidas de talla, la de engalanarlas con lazos y cintas clavados sobre ellas y la de afear la belleza de la escultura con adornos igualmente distantes de su sencillez que de la santidad de los objetos que representan.

\section{Al tratar Ponz sobre el templo barcelonés de Santa Catalina escribía:}

No hay paciencia para ver que a una imagen de Nuestra Señora del Rosario (fig. 6), de mármol y acabada de todo punto, que se venera en esta iglesia con particular devoción, le hayan puesto sobre los vestidos que ya tenía de dicha materia otros de tela, haciéndola comparecer ridícula como V. se puede figurar, cuando antes con sus vestidos, que trazó el escultor, no lo era, habiéndolos adaptado con la conveniente propiedad a la figura. Dicen que fue dádiva de S. Pío V: tal vez el Santo Padre no la hubiera hecho a saber la extravagante transformación que le esperaba a su precioso regalo. Considere V. qué gentileza resultará a las figuras de invenciones tan extrañas practicadas, no solamente en esta imagen, sino en otras muchas también de la Virgen que en diferentes partes he visto: ni se qué razón puede haber (vaya de sermón) para acostumbrar la vista de los fieles a semejantes puerilidades, y a veces indecencias. Quisiera que me dijere el devoto dotado de discreción y de prudencia cuánto tiempo se tardaría en condenar un escrito que descubriese a nuestra Señora conforme yo he visto repetidas veces sus imágenes, con cotillas, escotes, pendientes, aderezos, collares, mucho encaje, y en fin con todos los atavíos de que hace pompa la profanidad y el lujo. Semejantes dijes no pertenecen a la Madre de Dios, ni en ellos consiste la majestad y modestia con que se ha de exponer a la veneración de los fieles. La Virgen no está así en el Cielo, ni en la tierra anduvo de este modo (Ponz, 1947, pág. 1226).

Muchas de estas imágenes vestidas son sencillas esculturas sedentes de la época bajomedieval que han sufrido aditamentos y transformaciones para poder adecuarlas al gusto de la época. A algunas hubo que cortarles las manos por no ser adecuadas, y en su mayoría llevan un armazón a modo de miriñaque para que el manto y la túnica adquirieran esa forma piramidal que caracteriza estas vírgenes diechiochescas. En las iglesias ricas se les hacía un basamento de metal noble, y en las pobres un simple armazón de madera era suficiente para poder ajustar el traje?

9 Entre las más profundas transformaciones se cuenta la de la Virgen de los Desamparados de Valencia. La imagen de la Virgen era yacente, ya que se llevaba reposada sobre el féretro de los ajusticiados y de los cofrades muertos. Se transforma en una escultura erguida por medio de un añadido en la parte posterior y un armazón para vestirla. Las transformaciones sufridas por esta imagen han sido estudiadas por C. Alarcón, La religiosidad popular española en tiempos de Carlos III, manuscrito inédito. Agradezo la consulta de este estudio, que ha resultado de una ayuda inapreciable para redactar estas páginas. Las conclusiones y parte de la documentación han sido publicadas en Alarcón Román, 1990. 
Fig. 7. Virgen del Sagrario. Grabado anónimo en cobre (s. XVIII) a devoción de Manuel de Medina.

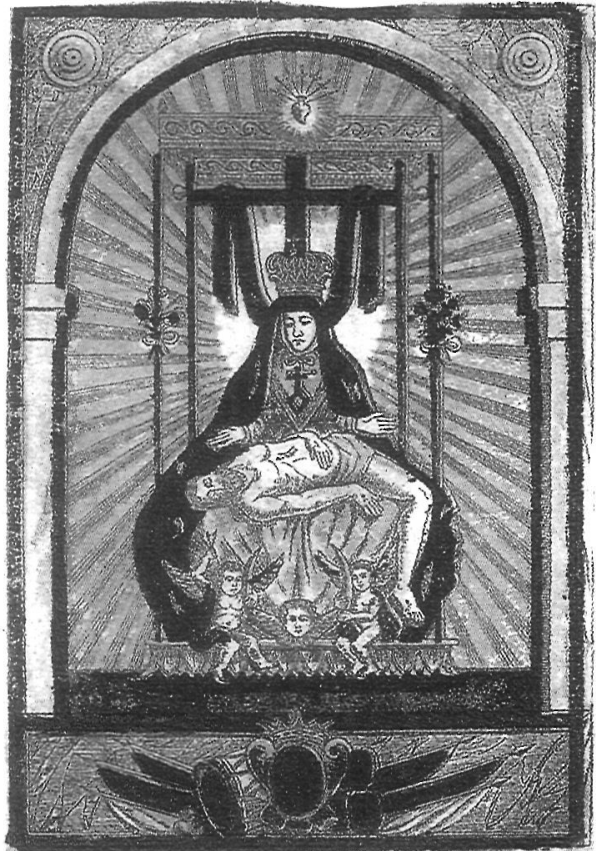

7 N NUESTRA SENOR F DE LAS AVGUSTIAS

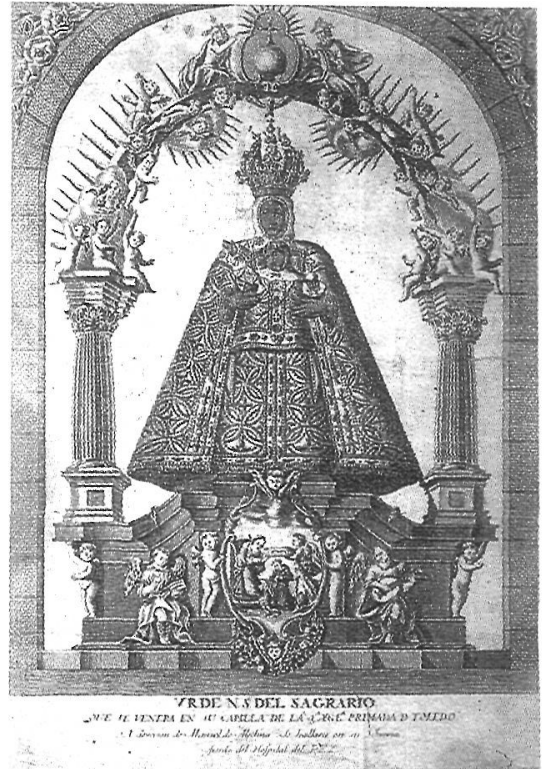

Fig. 8. Virgen de las Angustias. Grabado anónimo en madera (s. XVIII), iluminado. 
Sobre la riqueza del vestuario de algunas vírgenes se puede ver la variedad que presentan en el vestido las estampas de las diferentes imágenes. Entre ellas destacan, por ejemplo, la Virgen del Sagrario de Toledo que se venera en la catedral Primada (fig. 7) o la Virgen de Atocha de Madrid (Arte y devoción, 1990, núms. 4-8), una de las más ricas por la especial devoción que sentían los miembros de la famila Real ${ }^{10}$.

La riqueza del vestuario impresionaba. Por ejemplo, se sabe que la Virgen de Montserrat, que es una talla de la primera mitad del siglo XII, contaba con medio centenar de vestidos en la época de la invasión francesa. No obstante, es cierto que dependía de la actitud personal la valoración que se hacía de la belleza de la imagen y su riqueza de vestuario. Por ejemplo, la Virgen de Guadalupe, que es una talla del siglo XII, era descrita en el siglo XVIII de esta manera por Vilafañe:

Está la prodigiosa imagen en sitio elevado del retablo, para que más y mejor campee su hermosura. Tiene de alto poco más de una vara, sin peana, y corona, que la hace al parecer de mayor estatura. El color es moreno y el rostro es a maravilla grave y en todo perfecto, y causa tanta veneración a los que la miran que de puro respeto no se atreven a tener los ojos fijos en $\mathrm{Su}$ Divino semblante [...] Tiene la mano siniestra al Niño Dios, de extremada belleza y perfección, y en la derecha un cetro de oro, sembrado de piedras preciosas, como quien es Emperatriz de cielos y tierra: está vestida y tiene tanta diversidad de riquísimos vestidos, y tanta cantidad de preciosísimas joyas, que es cosa de admiración a quien la ve y registra despacio (Vilafañe, 1740, pág. 270).

De esta misma imagen Ponz hace este único y lacónico comentario:

Me aseguraron que los vestidos de la imagen pasaban de ochenta: vi entre ellos algunos cubiertos de pedrería, perlas, etc. y había uno que costó cuarenta mil ducados. Allí hay dones de reyes, reinas, príncipes y de otros grandes señores. En una alhacena, que llaman de la plata, se guarda (Ponz, 1947, pág. 1258).

Tan sólo una minoría accedía, por lo general, al conocimiento real de las sagradas imágenes, de ahí el interés de las descripciones, redactadas muchas de ellas en términos de admiración y adoración por haber llegado a participar de semejante intimidad. Por ejemplo, la imagen de la segoviana Virgen de Nieva fue descubierta según cuenta Vilafañe (Vilafañe, 1740, pág. 370) "11 "con mucha

10 Son muchas las imágenes de vírgenes vestidas: por ejemplo la Virgen de la Almudena de Madrid, la Virgen del Prado de Ciudad Real, la Virgen de la Natividad de Pinto, la Virgen de Piedraescrita en el retablo que existe en la iglesia parroquial del pueblo del mismo nombre en los montes de Talavera, la Virgen de los Nogales de la villa de Cameros, etc. De todas ellas se pueden ver estampas del siglo XVIII, tanto por mano de grabadores académicos como por artesanos. La diferente calidad de la técnica y el grabador es evidente en los ejemplos que reproducimos de las vírgenes del Sagrario y de Atocha. Sobre las imágenes vestideras véase Cea Gutiérrez, 1992.

11 En las descripciones se hace patente la diferencia existente entre las pequeñas dimensiones de la talla y la altura que suele alcanzar ésta cuando está vestida. 
reverencia y decencia por nuestro Reverendo Padre" para mudarla de vestido el 16 de Diciembre de 1624 , y con aquel motivo hubo algunos frailes que pudieron ver esta santa imagen:

Es de madera, y no se puede conocer qué madera sea, por el barniz que tiene; es de escultura, labrado todo el cuerpo con poca curiosidad; mas el rostro es hermoso, algo moreno, puede ser de la mucha antigüedad; la nariz aguileña bien sacada, derecha y muy proporcionada; las manecitas también, en buena proporción, ni muy llenas ni muy flacas; el rostro no es redondo; sino más largo que ancho; está sentada; los pies estriban como en un estradito, y representa el asiento más de escaño que de silla; las manos salían poco del cuerpo afuera, sin verse brazos, que los que ahora tiene son postizos; mas no lo eran las manos, que por haberse gastado mucho las tenía envueltas en un lienzo, guardadas y escondidas en el pecho. Desde la cabeza a los pies tiene media vara, y un dozavo; sale del lado izquierdo un Niño, no sentado ni torcido sino derecho, mas ladeado un poco, como que se inclina o reclina al brazo, con una tunicela desde el cuello abajo; tiene todo él una cuarta escasa; el color de la tunicela es colorado; parece también postizo, como el azul de la tunicela que de cuello a pies tiene la Madre, con un poco colorado a un lado.

Pero vestir y desvestir a las imágenes era un acto que requería un determinado respeto. Así en 1757 se observó en el vestir y desnudar la imagen de la Virgen de la Fuensanta en el presbiterio de la capilla mayor de la catedral; siendo forzoso "por su gran estatura" ponerla en un tapete en el suelo para poderle colocar los adornos correspondientes y desnudarla para vestirla de nuevo, "a vista de la mucha gente que suele concurrir por las verjas de dicha Capilla Mayor [...] lo que no es decente ni corresponde la veneración con que se debe tratar", acordará el Cabildo que siempre que se haya de vestir dicha imagen se hará en la sacristía, conduciéndola a ella con decencia, y estando allí con la misa "ínterin se le muda la ropa, cerrándose las puertas" (Peñafiel Ramón, 1988, pp. 89-90) $)^{12}$.

La Virgen de la Peña de Francia (Páez, 1981, núm. 1725-3) también era una imagen mariana medieval sedente:

En medio del retablo está el trono magnífico de plata en que se ostenta la gran Señora, la imagen sagrada de María rodeada de un arco de plata con lucidísimos rayos, corona imperial de oro filigranada en la cabeza, y en ella engastadas piedras muy preciosas. Vestidos según los tiempos, de mucho lustre y valor; y pendientes de ellos, joyas muy ricas. Sobresale a la parte exterior del arco una riquísima cama de plata con raso y primoroso arte labrada [...] Es la santísima imagen muy morena; y algunas veces se muestra tan agraciada y hermosa, que arrebata los corazones y se lleva los ojos hacia

12 Las hijas de la camarera, que llevaba 40 años en el cargo, se excusan de tener que hacerlo así "ante la estrechez de sacristía y falta de luz que hay en ella". El Cabildo exige a la camarera que se haga como se indica o renuncie al cargo, finalmente la camarera accede al deseo del Cabildo. 
sí misma. Pero en otras ocasiones (especialmente cuando hay tempestades) ostenta un rostro tan severo y airado que son pocos los que se atreven a mirarla de hito en hito [...] De los que hoy viven nadie la ha descubierto, porque hay tradición de que un prior quiso registrar la materia de que estaba fabricada (y es de madera sin duda) y la forma que tenía en lo interior; y quedó allí pasmado y sin poderse mover, persuadiéndose a que era castigo de su devoto atrevimiento (Caballero, 1728, pp. 79-80).

Caso distinto es el de la Virgen de las Angustias de Granada (fig. 8) que ha sufrido diversas transformaciones ya que en su origen era una Dolorosa a la que se añadió la imagen de Cristo muerto y la cruz en los siglos XVII y XVIII. Vestida de reina viuda como la Virgen de la Soledad de Madrid (fig. 1), los cambios sufridos por la imagen - debidos según parece a la necesidad de vestir a la Virgen- los describió en el siglo XVIII Sánchez Saravia ${ }^{13}$ de esta manera:

Dije ya el motivo de vestir a nuestra madre soberana con el traje que hoy se observa; en cuyos principios de él se significaban las manos de esta Señora unidas sobre el pecho, pero con la ofrenda que hizo el prelado del rico pectoral de corpulento tamaño pareció competente cerrar por el pecho la rizada túnica blanca, colocando en él esta preciosa alhaja, y separar manos y brazos, demostrándolos en acción más expresiva. Así se ejecutó, concurriendo a la disposición de este aderezo el eminente escultor [... Pedro Cornejo, que con la sabia pericia de su acierto proporcionó la acción con bello decoro, muy a satisfacción de los interesados, por los años de 1718. Dando comodidad para ello la situación de las manos ocultas, por estar comprimidas en el pecho, tendida una sobre otra; y como en la pintura y escultura sólo se atiende a la representación exterior del trasunto sensible, para componer el espíritu a la contemplación del objeto celestial, no se halla reparo en practicar lo expresado (Sánchez Saravia, 1777, pág. 29).

Las imágenes de los santos cambiaban normalmente poco en su aspecto. En ocasiones los artistas las vestían con los hábitos de alguna regla monástica porque, cómo anota Ponz en su obra, es "común entre nosotros el pintar a los Santos fundadores y aun a Nuestra Señora con los hábitos que presentemente se practican en ellas"14. No obstante había casos extremos que no se escaparon a los ojos críticos de los ilustrados. Fruto de una visita de Leandro Fernández de Moratín a la catedral de Córdoba es el siguiente comentario:

13 Parece que el Cristo muerto y la insignia de la cruz se pusieron a esta imagen dolorosa para que fuera igual a la pintura en tabla de la Virgen de las Angustias que regaló o trajo Isabel la Católica a Granada (citado por C. Alarcón, véase nota 19). La transformación de las imágenes religiosas ha sido una constante a lo largo de los siglos, incluso muchos de ellos se han llevado a cabo en época muy reciente como pone de manifiesto Villar Movellán, 1989.

14 Vestir con hábitos monásticos las imágenes también estaba prohibido por las autoridades de la Iglesia Católica ya que en 1642 el papa Urbano VIII (Bullarum, 1760, pp. 321-322) prohibió que "Jesucristo, la Virgen y los santos fueran pintados o esculpidos con el hábito de alguna orden religiosa particular, como las del Carmen o La Merced"; citado por Rodríguez G. de Ceballos, 1989, pág. 98. 
Siempre he oído citar a San Sebastián por ejemplo de desnudez; pero, ¿quién creerá que en esta iglesia, en la capilla que llaman de Villaviciosa, existe un San Sebastián muy jovencito, afeitadillo, con su peluca, su vestido de militar, su sombrero de tres picos debajo del brazo, sus flechas en la mano para denotar el martirio que padeció, su espadicico de plata, sus medias de seda, sus hebillas y sus zapaticos de castor? Yo pregunté por qué habían puesto de aquella manera al santo bendito, y me dijeron que era mayordomo de la Virgen, y estaba vestido de aquella manera para acompañarla con la decencia correspondiente en las festividades; a lo cual no hallé nada que responder (Fernandez de Moratín, 1867, t. II, pp. 17-18).

Pero dentro de esta temática de esculturas de bulto que podían ser vestidas ocupan un lugar privilegiado las pequeñas imágenes del Niño Jesús, por contarse entre los objetos más preciados de devoción, sobre todo entre las órdenes regulares femeninas. La presencia de imágenes del Niño en la calle debía ser bastante común. Blanco White hace el siguiente relato:

En los conventos de franciscanos están los donados que se dan al servicio del convento. Llevan el hábito de la Orden y son empleados en los oficios más bajos, a no ser que, si son capaces de representar o por lo menos de soportar la fama de una extraordinaria santidad, los manden a pedir limosnas para beneficio de sus señores. Todos los días se puede ver a estos santos idiotas caminar por las calles con pasos vacilantes y con el aspecto de la más profunda humildad ${ }^{15}$, paseando una imagen del Niño Jesús, a la que han adosado un cepillo para las limosnas, y ofreciendo no su mano, que es el privilegio de los sacerdotes, sino el extremo de su manga derecha para que 10 besen las personas pías (Blanco White, 1986, pâg. 180).

Por otro lado Ponz comenta que era habitual para el público la presencia del Niño en múltiples pinturas y la justifica incluso en aquellas composiciones en las que pudiera parecer un anacronismo, a pesar de que en opinión de este ilustrado era también censurable que los pintores los cometieran. Para Ponz se explica que en determinadas pinturas, como por ejemplo el Desposorio de Santa Catalina con el Niño Dios, San Antonio de Padua - a veces el Niño Jesús que lleva este santo recibe la atención por sí solo ${ }^{16}$ - San Ignacio de Loyola y otros muchos santos tengan al "mismo Niño en brazos" porque estas

15 Entre estos donados se encontraba el "hermanito Sebastián, penúltimo de los limosneros franciscanos en esta ciudad, del cual llevaba siempre una carta autógrafá manuscrita como amuleto el rey Carlos III, y como hubo que trasladarla a Roma para que fuera examinada en el proceso de beatificación, durante los días que no tuvo la carta el monarca no se atrevió a salir de palacio", según relato del mismo Jovellanos recogido por Blanco White, 1986, pág. 181. El retrato del venerable Fray Sebastián de Jesús Sillero, muerto en Sevilla en 1734, pintado por Gregorio Ferro "teniendo presente un retrato que se hizo en la vida del venerable, y un vaciado que se sacó después de muerto", fue grabado por Manuel Salvador Carmona en Madrid en 1782, y según la documentación conservada en el Archivo Histórico Nacional: "Esta obra se hizo a expensas del Rey Padre (que esté en gloria) por haber conocido y tratado en su infancia al dicho venerable cuando la Corte estaba en Sevilla" (citado por Carrete Parrondo, 1989, núm. 197).

16 Verdadero retrato del Niño de San Antonio que se venera en San Luis, y se lleva a los enfermos por los muchos milagros que hace $S_{u}$ Divina Majestad con ellos, grabada por Lorenzo Sánchez Mansilla (Arte y devoción, 1990, núm. 133). 


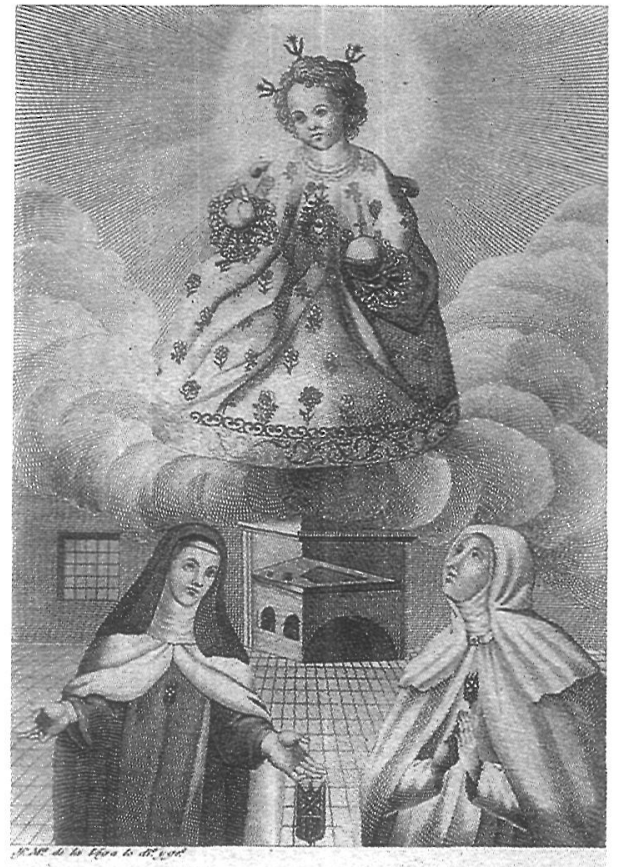

VA IMAGEN DE IESUS DEL DOLOR

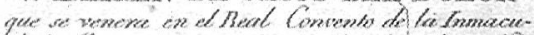

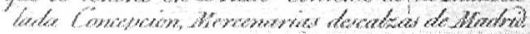

Fig. 10. Divino Emperador. Grabado en cobre por José Andrade, iluminado.
Fig. 9. Niño Jesús del Dolor. Dibujado y grabado en cobre por José María Ramos de la Vega.

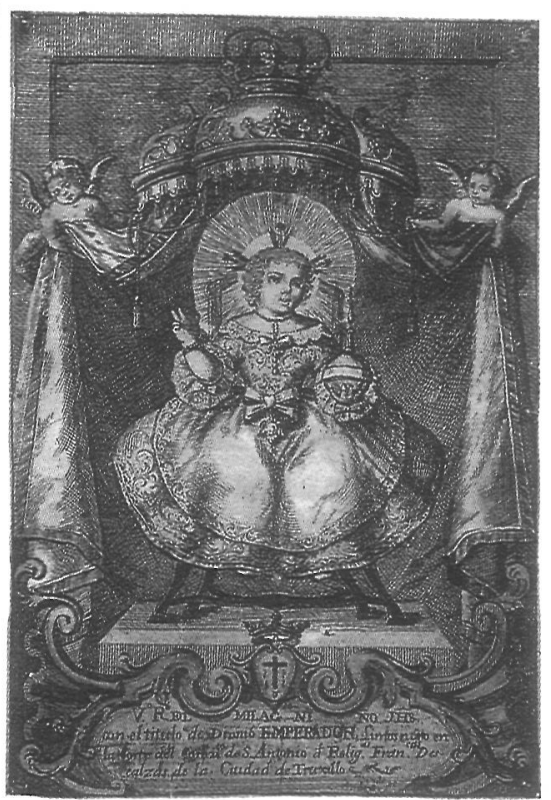


composiciones eran en realidad "piadosas representaciones de algunos favores que el Señor quiso hacer a aquellos siervos suyos; pues es cierto que su Majestad puede comunicarse a sus escogidos cuando y como quiere [...] Y el que pudo después de resucitado presentarse a la Magdalena en traje de hortelano, y en traje de peregrino a los discípulos de Emaús, puede también en forma de niño colocarse en los brazos de cualquiera de sus escogidos en esta vida mortal" (Ponz 1947, pág. 199).

En El pintor Cristiano y Erudito -obra a la que textualmente remite Ponz en este tema- Interián de Ayala comenta los errores que cometen habitualmente los artífices (Interián de Ayala, 1782 pág. 243), y le parece intolerable que pinten a "Cristo en su infancia enteramente desnudo" por considerarlo poco decente y decoroso, y añade: "No le representaron así los pintores y artífices antiguos, que atendían a la piedad y a la modestia, aunque en el arte de dibujar hayan sido muy inferiores a los modernos que ha habido en estos últimos tiempos: pero éstos, por persuadirse que el representar los cuerpos enteramente desnudos es cosa de más primor y artificio, han seguido este modo de pintar; olvidándose tal vez de que en todas las imágenes sagradas, principalmente en las de Cristo y de su Purísima Madre, se debe hacer mucho aprecio". Tampoco le gusta a Interián el ver pintado "con mucha frecuencia a Cristo como niño y aun como muchacho ya grandecillo, divirtiéndose en juegos pueriles: por ejemplo, cuando le pintan que está jugando con un pajarillo, teniéndole atado con un hilo y llevándole en sus manos o cuando le pintan montado a caballo sobre un cordero o de otros modos semejantes. Todo esto y otras cosas a este tenor son meras necedades y bagatelas [...] No se ocupaba en esto Cristo Señor nuestro, aun en la edad pueril: cosas mucho mayores y más graves revolvía en su mente santísima, con cuya memoria, a no haber sujetado sus pasiones con su soberano imperio, podía haberse contristado y entristecido. Tenía además perfectísimo uso de razón, no sólo desde que nació sino desde el primer instante en que fue animado y concebido [...] Por lo que no es razón que le imaginemos ocupándose en juegos pueriles y de niños, sino en pensamientos y meditaciones muy serias".

Es conocida la presencia de pequeñas imágenes del Niño Jesús en diferentes ámbitos - seglares y religiosos - y en diferentes clases sociales, ya fueran de bulto, ya en estampas. Pero donde más imágenes de bulto del Niño Jesús existían era en los conventos de monjas (fig. 9); según W. Coxe en su obra L'Espagne sous les rois de la maison de Bourbon también era común entre las monjas españolas llevar consigo un Jesús de cera al que se entretenían en vestir como a un muñeco (Fernández de Moratín, 1968, pág. 178) ${ }^{17}$. Parece mera variante

17 El mismo Moratín en el acto I (escena II) de esta obra pone en boca de doña Francisca la siguiente relación de objetos de devoción: "Pero mire usted, mire usted (Desata el pañuelo y manifiesta algunas cosas de las que indica el diálogo) cuántas cosillas traigo. Rosarios de nácar, cruces de ciprés, la regla de S. Benito, una pililla de cristal... Mire usted qué bonita. Y dos corazones de talco... ¡Qué sé yo cuánto viene aquí!... ¡Ay!, y una campanilla de barro bendito para los truenos... 
de la tradición de los Cristos vestidos y adornados por los feligreses. Llompart anota que en todos los conventos de clausura de Mallorca se conserva un elevado número de imágenes del Niño Jesús de los siglos XVII al XIX, en general de más devoción que valor artístico (Llompart, 1982). Un tipo corriente es la devoción del Nombre de Jesús: de pie, bendiciendo con la derecha y sujetando la esfera del mundo con la izquierda (fig. 10); los niños que aluden a la Pasión, de la manera que comentaba Interián de Ayala, durmiendo sobre la cruz o llevándola, o por ejemplo el tipo de Niño similar al que perteneció a la infanta Margarita durante su vida en el monasterio de las Descalzas Reales - donde en la actualidad se conservan unos 32 niños Jesús, ya que en casi todas las celdas de las monjas había un pequeño altar para ellos-: la infanta llevaba siempre en el cesto de labor o en el bolsillo del delantal un Niño dormido que estrechaba como preciados juguetes la cruz, la lanza, la corona de espinas y el sudario, símbolos de la Pasión ${ }^{18}$.

Como hemos visto hasta ahora, lo normal es que estas imágenes recibieran también un tratamiento especial en el vestido, como es el caso del Santo Niño del Remedio (Arte y devoción, 1990, núms. 130-132). Es muy interesante comprobar que algunos recibían una vestimenta un tanto extravagante, motivo de irónica crítica por parte de Blanco White:

Es muy corriente en España la representación de Dios en forma de niño. En muchos conventos el número de pequeñas imágenes del Niño Dios o el Niño Jesús, de un pie de altura, es casi igual al número de monjas, que lo visten con todas las formas del vestido nacional: de clérigo, de canónigo, en hábitos corales, de doctor en teología, de médico con su peluca y bastón de puño de oro, etcétera. También se ven muchas imágenes del Niño Jesús en las casas particulares; y en algunos lugares de España en que la principal ocupación es el contrabando, también se le puede ver vestido de contrabandista, con pistolas a la cintura y su trabuco en la mano (Blanco White, 1986, pp. 345-346).

Es posible que Blanco exagerara, pero el mismo Ponz, cuando visitó el monasterio de Guadalupe comenta:

El tabernáculo, que debía ser lo mejor por lo que en él se deposita, es de pésimo gusto ¿Y creerá V. que encima de él hay un Niño Dios vestido de militar? Cosa bien ridícula en una iglesia de esta seriedad (Ponz, 1947, pág. 606).

Aunque, es cierto, que en la posterior edición anota que "hay noticia de que se le ha mudado de traje".

¡Tantas cosas!". Entre estas cosas también se encontraba una figura de "Santa Gertrudis de alcorza"; la alcorza es una pasta muy blanca de azúcar y almidón con la que se cubren dulces y se hacen piezas o figurillas.

18 Esta iconografía es bastante común en las estampas dedicadas al Niño Jesús. Sobre estas imágenes en el convento de las Descalzas véase Ruiz Alcón, 1965; resulta también interesante el inventario de este tipo de figuras de bulto redondo realizado por Herrero Sanz, 1990, y Vega Jiménez, 1984. 
Fig. 11. Buen Pastor.

Grabado anónimo en cobre en 1820.

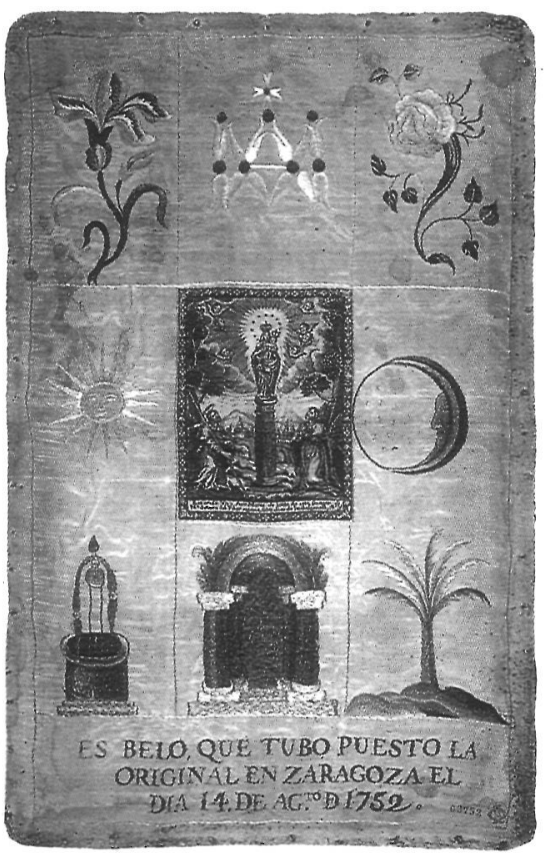

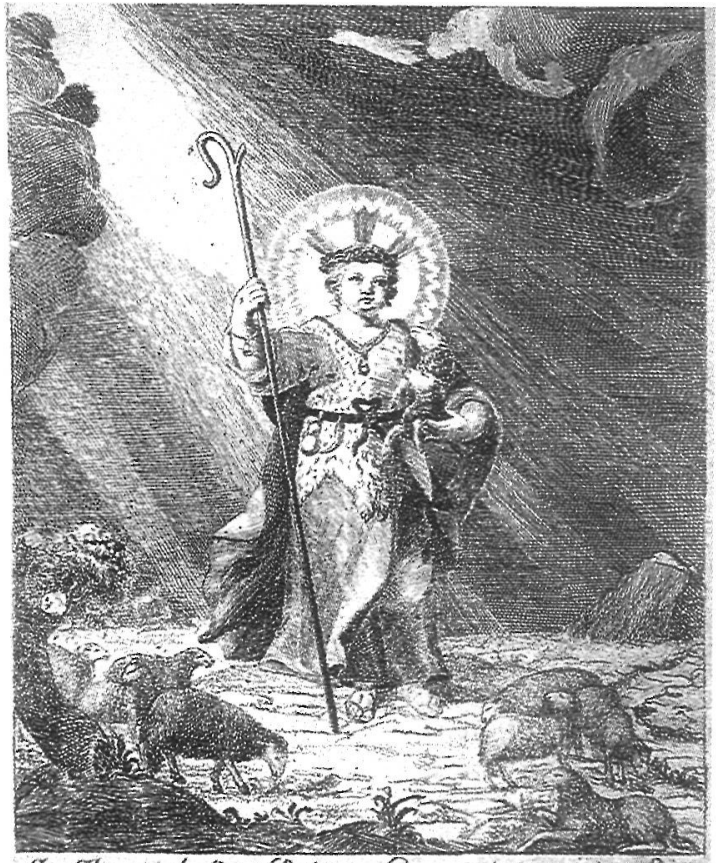

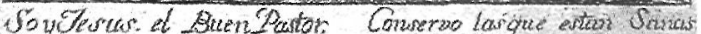

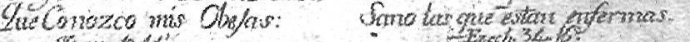

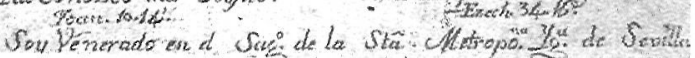

Fig. 12. Virgen del Pilar. Grabado en cobre y estampado sobre una parte del velo "que tuvo puesto la original en Zaragoza el día 14 de Agosto de $1752 "$. 
Pero quizá lo más interesante, pero ser sin duda lo más irracional, es que a las sagradas imágenes del Niño les añadían elementos propios de los niños de la época, educados en un ambiente supersticioso de protección a la infancia. La ignorancia seguía colocando a los niños amuletos para combatir el mal de ojo, incluso entre los vástagos de los grandes. En Feijoo encontramos una dura crítica a aquellos que creen "que los niños hermosos están más expuestos a este daño; porque la ternura de su edad es más capaz de recibir la maligna impresión, y la hermosura excita la envidia en los que la miran". Esos niños iban cargados de adminículos para ahuyentar todo tipo de efecto maligno sobre ellos:

Un chupador de cristal con cerco de plata; una uña de gran bestia (cuanto más peluda mejor) para ahuyentar las brujas, una esquila de plata, una higa de azabache y coral con la medalla de San Benito, un ochavo segoviano con un agujero y un cascabelero en forma de semicírculo ${ }^{19}$.

La representación más crítica de esas creencias la podemos ver en el Capricho 4 de Goya, El de la royona; del ceñidor que lleva el niño cuelgan dos higas para conjurar el mal de ojo, un escapulario o estampas de efectos milagrosos y una campanilla ${ }^{20}$. El empleo cotidiano de objetos religiosos como protectores de la infancia hizo que incluso aquellos que lo aprobaban reclamaran una cierta dignidad en su uso como, por ejemplo fray Jaime Barón y Arín, en Luz de la Fe (1717).

Pero también podemos apreciar elementos semejantes en figuras del Niño Jesús. El Buen Pastor (fig. 11) lleva en el cinto un colmillo y al cuello un tipo de medalla imposible de identificar; los conocidos como Niños de Pasión tienen, entre los símbolos que parecen bordados en el vestido, una higa, y la imagen responde a una forma tradicional de representación cuyos orígenes en estampas lo podemos rastrear hasta los comienzos del siglo XV y la pervivencia hasta finales del siglo $\mathrm{XIX}^{21}$; por último, el Santo Niño del Remedio (Arte y devoción, 1990, núm. 130) que lleva una campanilla, una higa y los Evangelios, destaca por su dieciochesca vestimenta y nos da una idea de cómo se podía llegar a vestir este tipo de imágenes.

Aunque en algunas de las estampas que hemos comentado se ve la transformación que sufren las imágenes dependiendo del gusto reinante o del

19 Félix Ponce de León, Vida, hechos y aventuras de Juan Mayorazgo, cap. citado por Mercader Riba y Domínguez Ortiz, 1972, pp. 119-120.

20 Este Capricho ha sido estudiado por Alcalá Flecha, 1987. Este autor ha hecho una exhaustiva búsqueda de textos coetáneos relacionados con la obra de Goya, Alcalá Flecha, 1988. Sobre las higas véase Hidburbh, 1955.

21 Por ejemplo, se puede mencionar la estampa del Evangelio según San Mateo, perteneciente al Rationarum Evangelistarum de 1510, reproducido por Westheim, 1981, pág. 78. Llompart, 1982, reproduce uno casi idéntico titulado Lo dulcissim nom de Jesus y publicado en la Imprenta de Pau Roca de Manresa, carrer de S. Miquel en 1865; el estudioso identifica el atuendo como de tiempos velazqueños. 
que se desea imponer, las innovaciones iconográficas son bastante limitadas. Para Bialostocky, "las transformaciones iconográficas significan vida, cambio, movimiento, renovación, en oposición a las fuerzas de la tradición, de la inercia o de la inmovilidad. El arte popular, ni el individual ni el tradicional, apenas presenta transformaciones iconográficas, o sólo en una medida muy escasa. Las imágenes de este arte son transmitidas con muy pocos o ningún cambio. Lo mismo ocurre en el arte religioso ortodoxo. En contraposición a esto, cuando más importante es la participación de la individualidad de un artista en una época histórica, tanto más variadas y numerosas son las transformaciones iconográficas que aparecen en dicha época" (Bialostocky, 1972, pp. 111-112). Se da una verdadera resistencia por parte del vulgo a sustituir una imagen de su devoción por otra, aunque sea más adecuada. Éste sería el caso comentado por Ponz en Cádiz:

En las iglesias de regulares nada hay de nuevo, excepto haberse renovado el culto público a un muy antiguo crucifijo que se veneraba en la de los reverendos Franciscanos de la Observancia. Según noticias [...] esta santa efigie, que es vaciada en pasta de papel, fue obra original de un indio en qué sé yo qué provincia de América [...] Hará poco más o menos cuarenta años que, sorprendida la procesión en que se conducía el crucifijo por una recia turbonada, no pudo evitarse que el agua hiciese un estrago tal en la pasta de papel, que por poco se hubiera disuelto [...] En este triste estado se emprendió la reparación; y si la efigie era disforme cuando salió de su primera mano, puede usted inferir qué tal quedaría después de restaurada con tales disposiciones.

Doce años hará que algunos caballeros cofrades trataron de colocar en su lugar un crucifijo de mejor forma; que en efecto lo hicieron venir de Nápoles; pero no bien apareció en el altar, cuando el pueblo que se dice piadoso comenzó (como los judíos contra el divino original) a gritos contra la imagen [...] Lo cierto es que al cabo de poco tiempo, ha sido depuesta la moderna y restituida la antigua a su lugar primero" (Ponz, 1947, pp. 15634).

Por cuestiones de espacio no vamos a tratar aquí por extenso el tema de las imágenes de Cristo. Éstos son igualmente vestidos, aunque no con tanto adorno como las imágenes de la Virgen. Por lo general se les colocan enaguas de lino y faldones de colores y adornos diversos, y les ponen pelucas de pelo natural largo encima de su cabellera original. Richard Twiss, en su Viaje por España y Portugal (1773), encontró en El Escorial el famoso crucifijo cincelado por Cellini, pero cuando lo vio su mitad inferior aparecía ridículamente cubierta por un terciopleo morado y un corpiño bordado en oro. Por último, podemos anotar algunos textos elocuentes sobre la imagen del Cristo de Burgos. Pedro de Loviano lo describía de esta manera en 1740:

Es tan admirable su arquitectura y su contextura tan rara, que toda es naturalmente tratable, y flexible de suerte que cede fácilmente en cualquiera parte que le apliquen el dedo, como si fuera de carne. La sagrada cabeza la tiene inclinada al lado derecho y se deja mover con facilidad al lado 
contrario y sobre el pecho [...] Su rostro es tan representativo del Divino original, de aspecto tan venerable, que [...] ha sucedido no poderle mirar de cerca con atención algunas personas de valor y esfuerzo, que se han empeñado en verle cara a cara [...] El cabello, barba y uñas exceden en propiedad las perfecciones del arte: porque imitan tanto lo natural, que parecen nacidos de la misma imagen. Tiene el brazo izquierdo algo más delgado que el derecho; lo que es o propiedad que imita la naturaleza, o lo que consideran algunas almas contemplativas en el original, que habiendo clavado al Redentor un brazo en la Santa Cruz porque el otro no llegaba al barreno correspondiente, se la tiraron y extendieron hasta que alcanzó la mano al lugar destinado para el otro clavo. Los nervios, arterias y huesos se perciben en número de un cuerpo perfectamente orgánico, siendo una extensión tan descubierta que en su modo se le adapta la frase, con que David explicó la extensión del Redentor en la Cruz, diciendo que se le podían contar todos sus huesos. Las llagas de los azotes [...] las heridas y la sangre pendiente de ellas tiene tales matices que parece se acaban de sellar en el original mismo [...] Finalmente, la estatura de la Santa Imagen es de hombre perfecto, y le hace hermosísima la misma fealdad de las llagas.

La realidad es que en el siglo XVII los escultores castellanos y andaluces, acaso más todavía que los pintores, dan a la imaginería religiosa un aspecto material terrible, reproduciendo las manifestaciones físicas del dolor en heridas, llagas, lágrimas, rostros abatidos, etc. Estas formas de representación que ya horrorizaban a los ilustrados eran, no obstante, del gusto de las gentes, ya que éstas se encontraban verdaderamente atraídas por las secuencias e historias cruentas: a través de la literatura de cordel, son las vidas de santos más melodramáticas y violentas las que tienen un público más popular.

\section{Para Ponz esta imagen sólo fue merecedora del siguiente comentario:}

Es ésta la iglesia que posee la comunidad de padres agustinos, donde se venera la milagrosa imagen que todos conocen por el nombre del Santo Cristo de Burgos, y ya sabe usted los prodigios que de ella se han escrito y la historia del mercader de Burgos que volviendo de Flandes la encontró, y cómo es tenida por obra de Nicodemus, que ciertamente hubiera sido este varón un escultor incansable si hubiera ejecutado todas las imágenes que se le atribuyen. La capilla donde está el Santo Cristo es muy rica de alhajas presentadas por soberanos y personas poderosas, con cuarenta y ocho lámparas de plata y de la misma materia son frontal, candeleros, gradas, rejas, etc. (Ponz, 1947, pág. 1048).

Resulta mucho más interesante la opinión de Jovellanos. En sus Diarios comentaba la visita realizada al convento en Abril de 1795 en estos términos:

Ayer tarde vimos también el Santo Cristo de Burgos en el convento de agustinos; su capilla, una gruta por la forma y la oscuridad; cincuenta lámparas, nueve de enorme tamaño, dos arañas, frontal, retablo y dosel de plata maciza; tres cortinas corridas, una en pos de otra, con mucho aparato, mucho encendimiento de luces, mucha devoción del vulgo; al fin, una efigie de malísima y hórrida forma; la mayor parte de las lámparas, dotadas; dentro y fuera de la capilla y por todo el claustro, carros de muletas, de piernas y brazos, y tetas de cera y aun de plata, votos, testimonios de estupidísima 
superstición. El fraile vende cruces de plata de varios tamaños y labores, estampas, medidas, todas tocadas a la efigie, en que ganará ciento por ciento (Jovellanos, 1992, pág. 219).

Otro tema de interés, por tanto, era la forma de presentación de las imágenes al público y el tipo de objetos que podían ser vistos en los santuarios. En el santuario de la Virgen de la Peña de Francia, según descripción de Domingo Caballero, se veía lo siguiente:

Las paredes de la iglesia están llenas de cuadros, lienzos y pinturas que expresan los innumerables milagros, pieles de lagarto o caimanes. Es tradición de los naturales que antes de aparecer la santa imagen salían de aquellos riscos aquellas serpientes, y hacían graves daños en hombres y animales: y que después, por intercesión de María Santísima, mediando súplicas y rogativas de los pueblos en esta su casa, los mataron milagrosamente y trajeron sus pieles por despojos de su iglesia (Caballero, 1728, pág. 78).

Además de estos monstruos sigue enumerando otros exvotos:

Hay también muchísimas cadenas de cautivos. Hay banderas, fusiles, mosquetes, bombas, muletas, velas y mortajas, todo prueba de los innumerables milagros de la imagen. Al lado derecho del coro, en lo bajo, está la sacristía vieja, y al siniestro lado la cerería, en donde se dan o escriben las limosnas de los votos; y se dan también medida y medallas de Nuestra Señora y hay efigies de cera, que según el voto de cada uno las paga y las pone tiempo determinado en el altar de Nuestra Señora.

La imagen más crítica de lo que podía ser uno de estos rincones la podemos apreciar en la estampa de Goya ;Qué locura! perteneciente a la colección de los Desastres de la guerra; en la parte derecha de la composición se puede ver un revuelto de estampas, exvotos, piernas e imágenes de cera, muleta, etc. Aunque sabemos que en estos santuarios vendían muchos de estos objetos devocionales - contar con una imagen milagrosa y sanadora reportaba pingües beneficios económicos al centro-, hay que apuntar la existencia de un arte popular referente a los exvotos pintados o de cera, que eran fabricados por artífices especializados de vida itinerante. Por ejemplo, hasta época reciente ha existido la figura del cerero que iba por distintas localidades y según la necesidad de la gente y por medio de los distintos moldes de los que disponía, elaboraba el exvoto deseado: niños, piernas, brazos, cabezas..., que podían ser huecos o macizos, según la situación económica de la persona que los encargaba (García Román y Martín Soria, 1989, pág. 356). En este sentido conviene recordar que estos vendedores tenían otro tipo de cliente, aquellos individuos relacionados con el mundo de la brujería y los hechizos, ya que no es raro encontrar figuras de cera entre las pertenencias de las hechiceras. El mismo Goya en los Caprichos dejó algunas imágenes del uso de estas figurillas de cera que representaban a niños: 44 Hilan delgado, 45 Mucho hay que chupar, y 47 Obsequio al maestro ${ }^{22}$.

22 Goya cuando quiere expresar claramente que son niños lo hace incluso dentro de los mismos Caprichos. Nos referimos no sólo a los que aparecen en Que viene el coco o Si quebró el 
Curiosidades al margen, también conviene recordar, aunque no nos vayamos a ocupar de ello, que existían profesionales de pintar exvotos. Suelen ser pintados sobre tabla, de forma casi siempre rectangular, a menudo mal labrada y preparada, y se suele emplear el óleo. En ocasiones se utilizan las estampas de la propia imagen del santuario para hacer, a modo de collage, el exvoto.

La manipulación o embellecimiento de las estampas fue algo común en el siglo XVIII. Entre las estampas era habitual que las más lujosas fueran estampadas en tafetán o seda; había quien se ocupaba en adornarlas y embellecerlas a través de bordado o sirviéndose de papeles de colores como la de la Virgen del Rosario (fig. 13); también son muy frecuentes las que están iluminadas o estampadas en una tinta de color.

Por último, nos vamos a ocupar brevemente de algunos aspectos de la estampa como objeto de uso e, incluso, veneración. Cuando, por ejemplo, el maestro Juan de Ávila en la primera parte del Epistolario Espiritual ${ }^{23}$ escribía a cierto prelado de Granada acerca de lo que creía que se debía hacer en su diócesis para adoctrinar a la gente de los pueblos, indica que consideraba útil que los predicadores y misioneros llevaran no sólo rosarios, cartillas y libros devotos, como los de fray Luis de Granada, sino también "algunas imágenes del santo crucifijo y Nuestra Señora y San Juan, para que las diesen a los pobres", poniéndoles algunas imágenes en las casas y añade: "Y los pueblos han menester todas estas salsas para comer un manjar: rosarios, imágenes han de ser muchas, y los ricos cómprenlos de las ciudades" (Caro Baroja, 1985, pág. 126).

De cómo era la venta en las ciudades, al margen de aquellas estampas que se podían adquirir en las librerías, da testimonio al escrito de 1740 del Marqués de la Villa de San Andrés:

Andan por el día un enjambre de embusteros con estampitas de santos o con imágenes de bulto pidiendo limosna por las casas; suben como por la suya propia, y si los encuentran dan a besar el santito, besan si pueden a las criadas, gorran sus cuartejos a lo menos, pero si no los encuentras, con lo que encuentran ellos se vuelven a bajar las escaleras (Domínguez Ortiz, 1970).

cantaro, sino al que sirve de fuelle en la escena de brujería del Capricho 69, Sopla, o al que lleva en brazos la figura monstruosa que aparece detrás en esta misma estampa. Las figurillas que se ven en los tres caprichos que comentamos no parecen realmente humanas y no son tan horribles como deberían ser si en realidad se tratase de verdaderos fetos, según describen algunos estudiosos de esta colección, sino que se parecen bastante a la que se ve en el "santuario" de los Desastres. Por otro lado, como comenta Bozal, 1992, pág. 32, al tratar del Capricho 52, composición que podría ser una crítica a la devoción a las imágenes piadosas si no fuera por la presencia de brujos y brujas volando, "la devoción a las imágenes - simple madera revestida- es tan irracional como la brujería, pertenece al mismo orden de cosas".

23 La primera edición es de 1578. Hay edición de 1618. Se tradujo al italiano, francés e inglés. En el siglo XVIII se publicó formando parte de sus Obras, Madrid, Imprenta de Ortega, 1759-1760 en 9 vols. y nuevamente en 9 tomos en Madrid Imprenta Real, 1792-1806. 
Los grandes santuarios, al extender su culto y devociones y pedir ayuda económica a las gentes por los pueblos, daban a cambio medallas, estampas, crucifijos, etc. De ahí que se procurara evitar por todos los medios los fraudes. El convento de Santa María de Nieva, por privilegio dado por Felipe V en 1733, era el único que podía imprimir, fundir y vender estampas y medallas con el título de su Virgen, o dar licencia al platero o impresor que quisiera hacerlo. La razón es que tanto las estampas como las medallas debían estar tocadas a la mano derecha de la imagen de la Virgen, "donde el poder de su precioso Hijo tenía formada la figura o materia de un rayo" de manera que aquellas personas que las llevaban "iban seguras de cualquier peligro". De lo que se deduce que aquellas que no habían sido tocadas al original no tenían supuestamente el poder de librar de rayos y centellas, por lo que eran un engaño. Los puntos de venta y distribución de estampas y medallas de Nieva que se ajustaban a la legalidad estaban, además del convento donde se encontraba la imagen, en los conventos dominicos del Rosario de Madrid, San Pablo de Valladolid y Santa Cruz de Segovia. Debido a la producción fraudulenta llevada a cabo por muchos plateros e impresores, desde el convento segoviano se difundieron circulares de aviso entre grabadores y plateros, incluso entre buhoneros, de Segovia, San Sebastián, Alcalá de Henares, Granada, Córdoba, Ávila y Arévalo, para dar a conocer el carácter exclusivo que tenían sobre la producción. En 1768 se requisaron a estamperos, impresores y plateros de Córdoba estampas y medallas hechas sin licencia y sin tocar a la Virgen.

Existían además estampas especialísimas como la de la Virgen del Pilar, estampada sobre un trozo del manto que tuvo puesto la misma imagen (fig. 12), pero, por lo común, las estampas eran de papel y su presencia en un ambiente era casi sinónimo de humildad y austeridad. Por ejemplo la mayoría de los conventos veían adornadas las celdas de los religiosos o religiosas con estampas, en los hospitales sobre las cabeceras de las camas suelen verse estampas, etc.; quizá un ejemplo elocuente de devoción y austeridad sea el mismo Goya. En carta a su amigo Zapater le dice:

Para mi casa no necesito de muchos muebles, pues me parece que con

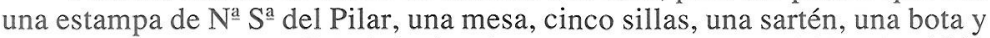
un tiple y asador y candil todo lo demás es superfluo (Goya, 1982, pág. 56) ${ }^{24}$.

La proliferación de las imágenes de papel en los distintos escenarios de la vida cotidiana fue exageradamente descrita por León de Arroyal:

La ciudad metrópoli tiene más templos que casas, más sacerdotes que seglares, y más aras que cocinas: hasta en los sucios portales, hasta en las infames tabernas se ven retablitos de papel, pepitorias de cera, pilitas de agua bendita y lámparas religiosas [...] Hasta los más recónditos y venerables

24 La estampa como objeto modesto y humilde, así como la figura del estampero y la función de las estampas en la sociedad barroca, han sido estudiadas por Portús, 1990. 


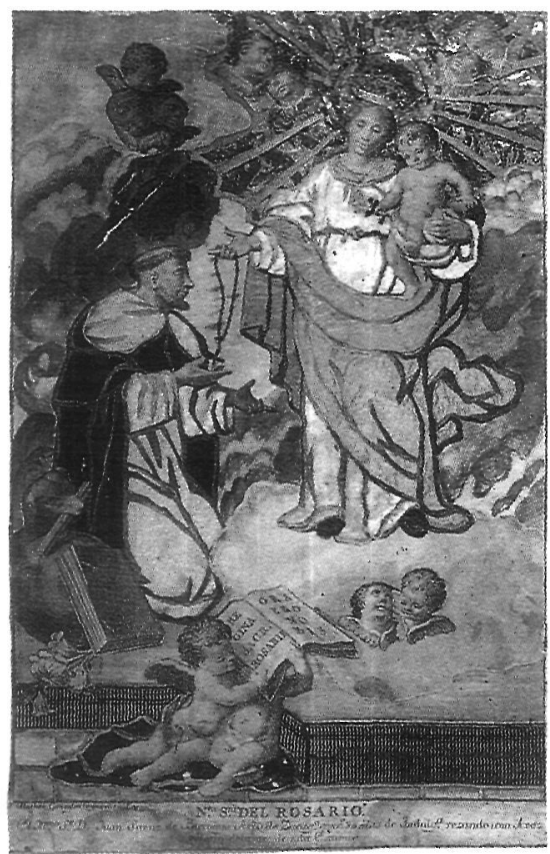

Fig. 13. Virgen del Rosario. Grabada en cobre por Mateo González, recortada con adiciones de bordados y pan de oro.

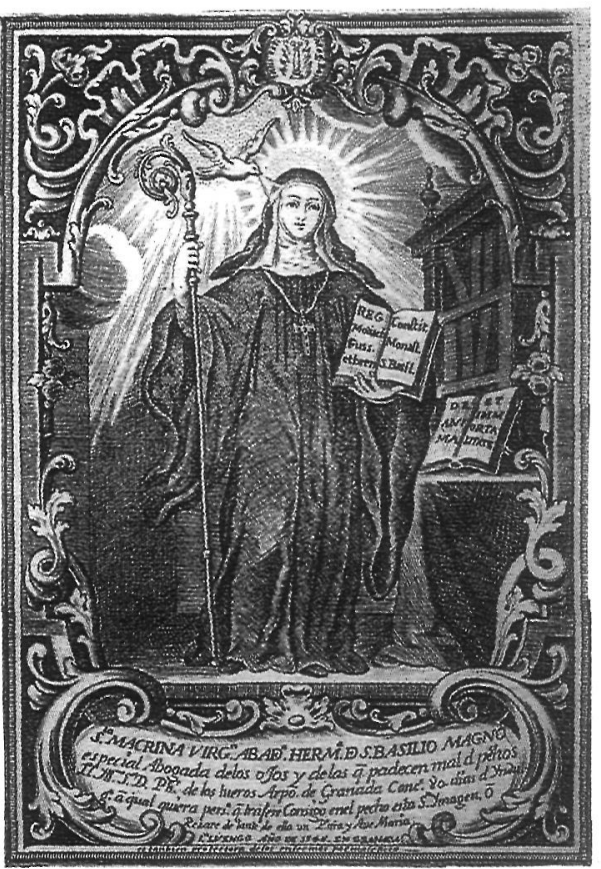


misterios de la religión se cantan por ciegos a las puertas de los bodegones al agradable y majestuoso compás de la guitarra (Arroyal, 1971, pág. 19).

Pero es que una sociedad desprotegida ante las enfermedades y las catástrofes naturales tenía lógicamente que buscar medios para prevenirse de estos males que la acosaban. En muchas ocasiones eran las estampas las que servían de talismán frente a los peligros, y su presencia era habitual en las casas según podemos ver en una pintura de Luis Paret (1991, $\left.\mathrm{n}^{\mathrm{O}} 28\right)$. Blanco White hace una elocuente referencia a esa intervención de los santos en la vida cotidiana de las gentes:

Las fiebres recurrentes, especialmente las tercianas y cuartanas, son muy generales en Andalucía, y es el verano la estación que más atacan [...] Está tan de acuerdo con las ideas católicas que haya un santo encargado del departamento médico de curación de fiebres, que ciertamente me sorprendería más encontrar una falta aquí que un dedo del pie no puesto bajo la influencia de algunas disposición de los cielos en la Vox Stellarum, libro que fue una de mis mayores sorpresas en Inglaterra. De hecho, esta parcela le ha tocado a San Bartolomé [...] Cada santo tiene su particular fantasía, desde San Antonio de Padua, que muchas veces retrasará hạcer un milagro hasta que no lo metan en un pozo o claven en la pared una estampa suya con la cabeza para abajo, hasta San Pascual Bailón, que atiende con preferencia a todo aquel que acompañe su petición con saltos y cabriolas. Con respecto a San Bartolomé, nada le inducirá a curar unas tercianas a no ser el voto de abstenerse el día de su fiesta de toda comida que no sea pan y fruta, precisamente lo mismo que, si no fuera por su milagrosa interferencia, causaría, según la opinión común, la recaída o agravamiento de la enfermedad (Blanco White, 1986, pág. 236).

En ocasiones se hacía un uso un tanto extravagante de este tipo de impresos para recuperar la salud. De nuevo White nos sirve de cronista:

En una de las principales parroquias de Sevilla hay una imagen venerada con el título de Virgen de la Salud. Esta denominación atrae a muchos a su santuario, que por estar enclavado en la parte más rica de la ciudad obtiene muchas y valiosas ofrendas. A cambio de ellas los fieles reciben una estampita o tira de papel impreso que contiene a intervalos regulares las palabras salus infirmorum en caracteres muy pequeños. En caso de enfermedad se recorta una de las líneas y se hace con el trocito una minúscula bolita que el paciente ingiere ayudado por un vaso de agua.

Y seguidamente comenta:

En la habitación de un enfermo grave suele haber más reliquias y amuletos que frascos de todas clases y hechuras en la alcoba de un inválido al cuidado de un boticario londinense. También cuando una señora está próxima a dar a luz sus amigas rivalizan entre sí para procurarle toda suerte de ayudas sobrenaturales [...] Hay dos cuya asistencia nunca deja de implorarse por medio de reliquias, cuadros o imágenes: los nombres de estos invisibles comadrones son San Ramón Nonato y San Vicente Ferrer.

En resumen, se ponían estampas de los santos protectores en el revellín de la chimenea contra las enfermedades en general, contra las más temidas o 
contra aquellas a las cuales la familia tenía más propensión. Frente a las epidemias, la gente tenía estampas de San Sebastián, San Roque o San Cristóbal, a fin de que les guardase de la peste; en las casas de campo cerca de la chimenea era común la estampa de Santa Bárbara, y era normal que la llevaran los caminantes para guardarse de los relámpagos y las tempestades. En ellas se puede apreciar la pervivencia de $\operatorname{los} \operatorname{modelos}^{25}$, o la mala factura de algunas estampas ${ }^{26}$ como la que llevaba al cuello Justo Martín, soltero natural de Castro de Fuentidueña de Segovia, que estando ebrio se coló en el cuarto de la reina en 1817; e incluso el uso indistinto que se hacía a veces de las oraciones para diferentes santos. Pero entre las estampas protectoras, sanadoras o defensoras las había con imágenes obviamente supersticiosas, y son aquellas que libran del maleficio como la de santa Macrina (fig. 15), que además de ser abogada de los ojos y de las que padecen mal de pechos, "es también protectora de los enfermos de maleficio", como abajo en letra muy diminuta se lee ${ }^{27}$.

Como es sabido, a principios del siglo XIX la sociedad española fue víctima de la sangrienta guerra contra los ejércitos napoleónicos, y son bastante numerosas las estampas que se conservan relacionadas con aquellos años fatales y sus consecuencias, para parafrasear el título que dio Goya a la colección que en la actualidad conocemos como los Desastres de la guerra. Es cierto que existían estampas con imágenes de abogados que libraban de la guerra, pero en esta guerra concreta sabemos que las estampas tuvieron una presencia activa. Por ejemplo, Lord Blayney, oficial inglés hecho prisionero por los franceses, por lo que atravesó la Península en su marcha hacia Francia, escribía en 1810 :

25 En la colección de A. Correa se conserva una estampa de santa Bárbara del siglo XIX en la que se ha empleado un taco grabado por Juan de Vingles, artífice de origen galo, activo durante el segundo tercio del siglo XVI en España.

26 El Santo Oficio prohibió algunas estampas por su tosca ejecución y las autoridades académicas tomaron medidas ante la mala factura de las imágenes religiosas, por ejemplo en los Estatutos, 1768, cap. XXXI, núm. 4 se dice: "Deseando que las imágenes sagradas se hagan con la perfección posible, y que la impericia de los que las forman no prosiga haciendo irrisibles los objetos de nuestra veneración. Prohíbo bajo la misma multa de cincuenta ducados, a todo profesor de pintura, escultura y grabadura, que no tenga licencia para ello de la Academia, pintar, esculpir, y grabar para el público Imágenes sagradas". El 12 de Febrero de 1817 se dictaba una real resolución para tomar nuevas medidas contra las imágenes religiosas deformes y mal ejecutadas, véase Vega, 1987, pág. 29. Agradezo a Teresa Fernández su amabilidad al haberme dado a conocer la existencia de la documentación sobre Justo Martín en el Archivo de Palacio.

27 Hay que tener en cuenta que las estampas se empleaban también por curanderas, hechiceras y brujas. La Inquisición prohibió algunas de estas estampas; por ejemplo en 1739 se prohíbe una estampa de San Antonio que decía: "quien tuviese su casa adornada con estas armas, será libre de incendio, de peste y de encantamiento". Y en 1733 se prohíben las de la Virgen de la Fuensanta y la de la Virgen del Pilar por llevar escrito: "Palabras santísimas contra hechizos, tempestades de rayos, brujerías, etc. por ser palabras de Dios mismo". Era habitual emplear contra el mal de ojo medallas de san Benito, estampas y bolsitas con los Evangelios; sobre este tema véase Carrete Parrondo, 1981, pp. 36-43. 
Sin duda es asombroso que de la encarnizada lucha que sostiene España no haya brotado un hombre de talento superior, mientras que la Revolución Francesa ha producido tantos, y en todos los géneros. Pero se debe atribuir a Ia influencia del clero, siempre demasiado severo con cualquier sistema de educación más liberal. ¿Qué energía se puede esperar de un pueblo que tiene más confianza en la protección de un santo que adopta como patrón que en su propio valor? El soldado que se creerá invencible porque lleva sobre su pecho una reliquia de un santo podra mostrar algún valor al marchar al combate, pero huirá en cuanto crea que su santo le abandona (Savine, pág. 99).

Sobre la valerosa actuación de las mujeres en el sitio de Zaragoza podemos añadir otro singular testimonio de la época referido a la circulación de estampas religiosas:

Las mismas mujeres se presentaron junto a los cañones que cebaron, dando sin cesar agua y vino a los artilleros, que no podían resistir más, animándolos con las expresiones más tiernas y diciéndoles: "Hijos, refrescaos que la Virgen nos asiste y favorece", y como había quien se dedicaba en distribuir estampas de Nuestra Señora del Pilar, todos las colocaron sobre sus sombreros (Memoria, 1808, pág. 38).

Y en la descripción de cómo era el ejército español que entró en Madrid el 14 de Agosto de 1808 Alcalá Galiano cuenta:

Pero la mayor parte de los nuevos huéspedes vestían los holgados zaragüelles y traían la manta al hombro; y en la cabeza, cuyo pelo caía por los lados y espaldas en largas mal peinadas y sucias melenas, sombrero redondo con escarapela patriótica, cintas con lemas y muchas estampitas con imágenes de la Virgen y de los Santos [...] Se iban a los conventos de monjas a pedir oraciones y algunas estampas para sus sombreros y pechos (Alcalá Galiano, 1955, pág. 353).

Pero introducidos en la guerra y en la crítica a la irracionalidad popular, nada hay mejor que la visión del propio Goya de estas devociones. Pertenecen las imágenes a la serie de los Desastres. Goya toma un tema del dominio público, y mezclado con hechos reales, configura una realidad irónica y amarga. En el desatre 66, Extraña devoción, el pintor ha tomado el tema del asno cargado de reliquias en clara referencia visual al asno portando el ídolo. Parece seguro que hasta el pueblo llano conocía esta fábula que Covarrubias ya recogió en su Diccionario y el mismo Lope de Vega empleó en una de sus comedias. Mas el asno de Goya porta unas reliquias concretas, las de la beata Mariana de Jesús, por la que sentía una gran devoción el pueblo llano de Madrid. Por el contrario, en el siguiente desastre, Esta no lo es menos, son dos imágenes de la Virgen las que aparecen: la Virgen de la Soledad (fig. 1) - a la cual se la tenía especial devoción para que conservara la salud del monarca-, y la Virgen de Atocha (Arte y devoción, 1990, núms. 4 y 5), en cuyas manos dejó el reino Fernando VII cuando lo abandonó en 1808 (Carrete Parrondo, 1981, núm. 308). La audacia de ambas composiciones sólo es comparable a la del comentario que lleva cada una de ellas. Los esfuerzos ilustrados cayeron en saco roto, y frente 
a la firme voluntad educadora de éstos, se estableció el régimen oscurantista del Deseado, que el mismo Goya reflejó en la parte final de su colección de estampas (Véase Vega, 1992). No cabe duda de que uno de los pilares en los que se asentó el regreso a la corona de Fernando VII fue la irracional devoción, la ignorancia y la ingenuidad popular.

\section{BIBLIOGRAFÍA}

ALARCÓN ROMAN, C. 1988. Catálogo de Amuletos del Museo del Pueblo Español, Madrid, Ministerio de Cultura.

- 1990. "La iconografía religiosa en el siglo XVIII", Revista de Dialectología y Tradiciones Populares, núm. 45, pp. 247-277.

ALCALÁ FLECHA, R. 1987. "El tema del niño mal criado en el capricho 4, El de la rollona, de Goya", Goya, núm. 198, pp. 340-42.

- 1988. Literatura e ideología en el arte de Goya, Zaragoza, Diputación General de Aragón.

ALCALÁ GALIANO, A. 1955. Obras escogidas, Madrid, Biblioteca de Autores Españoles, 2 vols.

ARES, A. 1640. Discurso del ilustre origen y grandes excelencias de la misteriosa imagen de nuestra Señora de la Soledad del convento de la Victoria de Madrid de la Sagrada Orden de los Mínimos de S. Francisco de Padua, Madrid, Pedro Taço.

ARROYAL, L. de 1971. Pan y Toros y otros papeles sediciosos de fines del siglo $X V I I I$, edición de A. ELORZA, Madrid Ayuso.

ARTE Y DEVOCIÓN. 1990. Arte y devoción. Estampas de imágenes y retablos de los siglos XVII y XVIIl en iglesias madrileñas, Madrid, Calcografía Nacional.

BIALOSTOCKY, I. 1972. Estilo e iconografía: contribución a una ciencia de las artes, Barcelona, Barral Editores.

BLANCO WHITE, J.M. 1972 Obra inglesa, prólogo de J. GOYTISOLO, Buenos Aires, Ediciones Formentor.

- 1986. Cartas de España, introducción V. LLORENS, Madrid, Alianza.

BOZAL, V. 1992. Instantáneas. Caprichos, Madrid, Turner.

BULLARUM. 1760. Bullarum, Privilegiorumet Diplomatum Romanorum Pontificum amplissima Collectio..., vol. VI, Roma, s.i.

CABALLERO, D. 1728. Historia de la admirable invención y milagros de la taumaturga imagen de Nuestra Señora de la Peña de Francia, patrona tutelar y defensora de Orán, Salamanca, Imprenta de la Viuda de Gregorio Ortiz. 
CARO BAROJA, J. 1985. Las formas complejas de la vida religiosa (Religión, sociedad y carácter en la España de los siglos XVI y XVII), Barcelona, Sarpe.

CARRETE PARRONDO, J. 1981. Estampas. Cinco siglos de imagen impresa, Madrid, Ministerio de Cultura.

- 1989. El grabado a buril en la España Ilustrada: Manuel Salvador Carmona, Madrid, Fundación Casa de la Moneda.

CEA GUTIÉRREZ, A. 1992. Religiosidad popular. Imágenes vestideras, Zamora, Caja España.

CENSOR. 1972. El Censor. Antología, edición de E. GARCÍA PANDAVENES, Barcelona, Labor.

CHRISTIAN, W.A. 1989. "Francisco Martínez quiere ser santero. Nuevas imágenes milagrosas y su control en la España del siglo XVIII", El Folk-lore Andaluz, núm. 4, pp. 103-114.

- 1990. Apariciones en Castilla y Cataluña. Siglos XIV a XVI, Madrid, Nerea.

- 1991. Religiosidad local en La España de Felipe II, Madrid, Nerea.

DOMÍNGUEZ ORTIZ, A. 1970. "Una visión crítica del Madrid del siglo XVIII. Hechos y figuras del siglo XVIII español", Anales del Instituto de Estudios Madrileños, vol. VI, pp. 313-316.

ESTATUTOS. 1768. Estatutos de la Real Academia de San Carlos, Valencia, s.i.

FERNÁNDEZ DE MORATÍN, L. 1867. Obras póstumas, Madrid, Rivadeneyra.

- 1968. El si de las niñas, edición de R. ANDIOC, Madrid, Castalia.

GARCíA ROMÁN, C. y M.T. MARTÍN SORIA. 1989. Religiosidadpopular: exvotos, donaciones y subastas, en C. ÁLVAREZ SANTALÓ, J. J. BUXÓ Y S. RODRÍGUEZ BECERRA (coords.), La religiosidad popular. III. Hermandades, Romerías y Santuarios, Barcelona, Anthropos, pp. 353-368.

GOYA, F. 1982. Cartas a Martín Zapater, edición de M. AGUEDA y X. SALAS, Madrid, Turner.

HERRERO SANZ, M.J. 1990. La escultura en el Convento de Agustinas Recoletas de Santa Isabel de Madrid, en Catálogo IV Centenario de la Real Fundación del Convento de Santa Isabel de Madrid, Madrid, Patrimonio Nacional, pp. 111-142.

HIDBURGH, W.L. 1955. "Images of the Human Hand as Amulets in Spain", Journal of the Warburg and Courtauld Institutes, núm. 18, pp. 67-89.

INTERIÁN DE AYALA, J. 1782. El pintor Cristiano y Erudito o tratado de los errores que suelen cometerse frecuentemente en pintar y esculpir la imágenes sagradas, Madrid, Joaquín Ibarra.

JOVELLANOS, M.G. de 1952. Obras, Madrid, Biblioteca de Autores Españoles, t. II. 
- 1956. Obras, Madrid, Biblioteca de Autores Españoles, t. III.

- 1992. Diario (Antología), edición de J.M. Caso González, Barcelona, Planeta.

LISÓN TOLOSANA, C. 1992. La bruja en España, Madrid, Ediciones Temas de Hoy.

LLOMPART, G. 1982. Imágenes mallorquinas exentas del Niño Jesús, en Religiosidad popular. Folklore de Mallorca, folklore de Europa, vol. I, Palma de Mallorca, J.J. de Olañeta Editor, pp. 73-84.

LOVIANO, P. 1740. Historia y milagros del Santísimo Cristo de Burgos con su novena, Madrid, Alonso Orozco.

LUIS PARET. 1991. Luis Paret y Alcázar 1746-1799, Vitoria-Gasteiz, Gobierno Vasco.

MARTÍNEZ-BURGOS GARCÍA, P. 1990. La imagen de vestir: el origen de una devoción barroca, en Pedro Mena y su época. Simposio Nacional, Málaga, Junta de Andalucía.

MEMORIA. 1808. Memoria de lo más interesante que ha ocurrido en la ciudad de Zaragoza con motivo de haberla atacado el Ejército francés, Madrid, Imprenta de la calle de la Greda.

MERCADER RIBA, J. y A. DOMÍNGUEZ ORTIZ, 1972. La época del Despotismo Ilustrado, Barcelona, Vicens Vives.

PAEZ, E. 1981-1983. Repertorio de grabados españoles, 3 vols., Madrid, Ministerio de Cultura.

PEÑAFIEL RAMÓN, A. 1988. Mentalidad y religiosidad popular murciana en la primera mitad del siglo XVIII, Murcia, Universidad de Murcia.

PONZ, A. 1947. Viaje de España, o Cartas en que se da noticia de las cosas más apreciables, y dignas de saberse que hay en ella, Madrid, M. Aguilar.

PORTÚS, J. 1990. "Uso y función de la estampa suelta en los Siglos de Oro (testimonio literario)", Revista de Dialectología y Tradiciones Populares, núm. 45 , pp. 227-246.

PUENTE, J. de la. 1968. La visión de la realidad española en los viajes de Don Antonio Ponz, Madrid, Moneda y Crédito.

RODRÍGUEZ G. DE CEBALLOS, A. 1987. Piedad y vida religiosa en la Corte durante el siglo XVIII, en El Real Sitio de Aranjuez y el arte cortesano del siglo XVIII, Madrid, Comunidad de Madrid.

- 1989. "Iconografía y Contrarreforma: a propósito de algunas pinturas de Zurbarán", Cuadernos de Arte e Iconografia, núm. 4, pp. 97-105.

RUIZ ALCÓN, M.T. 1965. "Imágenes del Niño Jesús del Monasterio-Convento de Las Descalzas Reales", Reales Sitios, núm. 4, pp. 28-36.

SÁNCHEZ LORA, J.L. 1989. Claves mágicas de la religiosidad barroca, en C. 
ÁLVAREZ SANTALÓ, J.J. BUXÓ y S. RODRÍGUEZ BECERRA (coords.), La religiosidad popular. II. Vida y muerte: La imaginación religiosa, Barcelona, Anthropos, pp. 125-145.

SÁNCHEZ SARAVIA, D. 1777. Compendio histórico del origen y culto en Granada de Nuestra Señora de las Angustias, Granada, s.i.

SAVINE, A. 1910. España en 1810, París, c. 1910, s.i.

VEGA, J. 1987. "Estampas del Trienio Liberal", Villa de Madrid, núm. 94, pp. 2852.

- 1992. Instantáneas. Desastres, Madrid, Turner.

VEGA JIMÉNEZ, M.T. 1984. Imágenes exentas del Niño Jesús. Historia, iconografía y evolución, Valladolid, Caja de Ahorros Provincial.

VELASCO, H.M. 1989. Las leyendas de hallazgos y de apariciones de imágenes. Un replänteamiento de la religiosidad popular como religiosidad local, en C. ÁLVAREZ SANTALÓ, J.J. BUXO Y S. RODRÍGUEZ BECERRA (coords.), La religiosidad popular. II. Vida y muerte: La imaginación religiosa, Barcelona, Anthropos, pp. 401-410.

VENTURA RODRÍGUEZ, 1983. El arquitecto D. Ventura Rodríguez (1717-1785), Madrid, Museo Municipal de Madrid.

VILAFAÑE, J. de 1740. Compendio histórico en que se da noticia de las milagrosas y devotas imágenes de la reina de los cielos y tierra, María Santísima, Madrid, Imprenta de Manuel Fernández.

VILAR MOVELLÁN, A. 1989. "Santos travestidos: imágenes condenadas", Cuadernos de Arte e Iconografía, núm. 4, pp. 183-191.

VILLEGAS, B. de. 1635. La esposa de Christo, instruida con la vida de Santa Lutgarda, Murcia, Juan Fernández Fuentes.

WESTHEIM, P. 1981. El grabado en madera, México DF, Fondo de Cultura Económica. 